Kaniye S. A. EbeKU*

\title{
Revisiting the Acquittal of 10 Policemen: Issues of Judicial Independence, Trial by Media and Fair Trial in Cyprus
}

\begin{abstract}
In a recent judgment in the Efstathiou case, the Assize Court of Nicosia, Cyprus, acquitted ten Policemen charged with criminal offences related to alleged beating in 2005 of two Cypriot students. That verdict led to spontaneous reactions across the country, with people publicly protesting against and criticizing the judiciary. Among those that made scathing public comments were the Attorney-General of Cyprus and senior Cypriot lawyers. In its judgment, the court had suggested that media comments about the case unduly interfered with the fair trial of the case and amounted to contempt of court. On the whole, this case raises the issues of independence of the judiciary, trial by media and fair trial. There are two opposing views on the propriety or otherwise of the media coverage of the case as well as on whether, and if so, to what extent, the judiciary can be properly criticized. Essentially, this article seeks to consider the issues of judicial independence, trial by media and fair trial as well as the closely associated issue of contempt of court arising from the Efstathiou case and in relation to the commonlaw rooted Cypriot legal system. It argues that the right to fair trial is an inseparable part of a democratic society and that while the right to freedom of expression is a fundamental human right and undoubtedly the bulwark of a democratic society, it is not realizable without an independent judiciary which is equally indispensable in a democratic society. Hence, there is a great need to recognize the limits of the right to freedom of expression in order to sustain the independence of the judiciary and ensure the right to a fair trial.
\end{abstract}

Keywords: Judicial Independence, Trial by Media and Fair Trial, Contempt of Court, Common-law/Commonwealth Countries, European Convention of Human Rights and European Court of Human Rights, Cyprus and Cypriot Law

The author dedicates this article to all those who believe in Judicial Independence world-wide.

\section{Introduction}

On 19 March 2009 the Assize Court of Nicosia, Cyprus, stirred up a hornet's nest by its decision to discharge and acquit the ten policemen accused of various criminal offences in the case of Republic v. Efstathiou \& Others. ${ }^{1}$ The criminal charges had emanated from an alleged incident of high-handedness and brutality visited on two hapless Cypriot students by the accused persons in December 2005. Importantly, the unfortunate incident was allegedly captured by a secret video which was repeatedly shown on television programmes and published in print and online newspapers before and allegedly during the trial. The revulsion of the civil society over the incident was great, and so was a yearning for the

* Professor of Public Law and Chair, University of Nicosia Law School, Cyprus. Also, Visiting Professor of Law, University of Kent Law School, Canterbury, UK.

I am indebted to Athanasiou Thanasis Michalakis for his research assistance in writing this article. I am also grateful to him for the generous support he extended to me during my six years sojourn in the Republic of Cyprus.

E-mail: ebeku.k@unic.ac.cy, ksael@hotmail.com

1 Republic v. Efstathiou \& Others (Case No. 17179/06), unreported Judgment of 19 March 2009 (Assize Court, Nicosia, Cyprus). 
perpetrators to face Cypriot criminal justice. Expectedly, the criminal justice system was put in motion against the accused persons and this ran into full course on 19 March 2009 with the verdict of the trial court (the Assize Court of Nicosia).

Going by media accounts of the incident, including the video footage, the accused persons were 'guilty as charged'. However, the three-member panel of judges that heard the case thought and decided otherwise; as earlier mentioned, they found the accused persons 'not guilty as charged' and accordingly set them free. This led to public outrage and spontaneous popular street protests against the Cypriot judiciary for what was considered to be an unjust decision. ${ }^{2}$ The next day and on several occasions subsequently, local newspapers were awash with various reactions to the judicial verdict-mostly critical of the decision (see below). Surely, this may well be excused going by the general public sentiment against that incident, though this is not to suggest that it was entirely proper. It may well be that the trial judges were wrong in their decision on the case. However, this is to be ultimately decided locally by the appeal court-the Supreme Court of Cyprus. ${ }^{3}$ Even so, there is no guarantee that the Supreme Court would necessarily satisfy the public's sense of justice. ${ }^{4}$

In the end, although the decision may rightly be criticized in the future for being erroneous in point of law (in the interim, it is sufficient to say that there are some difficulties in understanding the general approach and reasoning of the judges in relation to the merits of the case), it is important to consider, at this stage, the crucial issues raised by the various protests in relation to the working of the legal system. As will become clear below, the decision and various reactions thereto, have raised issues of independence of the judiciary, trial by media and fair trial. This article seeks to consider these issues here together with the closely related issue of contempt of court. As a point of departure, section 2 of this article will provide the background and context by outlining some of the reactions to the judicial

2 Public protests against the decision continued for several days and weeks. See Hazou, E.: Latest protests over police acquittal "We are not doing this for our own kids, but rather for the children of other families who might get the same treatment". [CyprusMail (Internet Edition), 24 March 2009]; Theodoulou, J.: Police beating appeal court date set for September. [CyprusMail (Internet Edition), 28 April 2009]. Note that all references here to articles published in the (CyprusMail Internet Edition) are permanently searchable through its website: $<$ http://www.cyprus-mail.com/news/>.

3 The Supreme Court set down 14-18 September 2009 for the hearing of the appeal filed by the prosecution. See Theodoulou: Police beating appeal... op. cit. However, it had to hear first a preliminary objection filed by counsel for the first respondent in the appeal seeking to dismiss the appeal in limine for abuse of judicial process in that the Attorney-General had issued public statements declaring lack of confidence in the Cypriot judiciary after the decision of the trial court in the case. Although the application was found to be almost on all fours with the decision of the Supreme Court in Constantinides v. Vima Ltd., Cyprus Law Reports, (1983) 348, the court was able to distinguish it, inter alia, on the ground that the Attorney-General was not a party 'stricto sensu' in the present appeal and accordingly dismissed the objection. The court frowned at the impugned statements, suggesting that they were contemptuous. However, that was not the question before them (only the 'contemnor' Attorney-General had the power to bring such contempt proceedings before the court). See AttorneyGeneral of the Republic v. Efstathiou (Criminal Appeal No. 56/2009), unreported Ruling (in Greek) of 8 October 2009 (Supreme Court of Cyprus, Nicosia, Cyprus). As at 22 March 2010 the appeal was still pending.

4 After exhausting the local remedies, the victims might further seek redress from the European Court of Human Rights (ECHR) in Strasbourg if they are unsatisfied with the outcome. In this regard, they would be suing the State for the violation of their human rights. However the accused persons, once acquitted by the Supreme Court, cannot be retried by the ECHR. 
verdict. This will be followed in section 3 by an analysis of the focal issues in the context of the Cypriot common-law rooted legal system, ${ }^{5}$ as influenced or modified by it's membership of the Council of Europe as well as the European Union. The last section, section 4, will be devoted to concluding remarks. It is hoped that this article will generate a lively debate, especially within the legal community in the country, which could lead to better appreciation of the working of the legal system by the general society and, perhaps, any necessary changes in the extant law.

\section{Public Reactions: Background and Context}

Media reports of reactions to the recent judicial verdict in the Efstathiou case show that they cut across the whole strata of the Cypriot society. Apart from the general public, there were also reactions from President Demetris Christofias of the Republic of Cyprus, senior Cypriot lawyers, professional associations (particularly the Cyprus Bar Association), and the Attorney-General of the Republic of Cyprus Petros Clerides. Furthermore, there was also a counter-reaction by the Supreme Court of Cyprus. For present purposes, some of those reactions-particularly those mentioned here-are briefly recounted hereunder.

It needs to be made clear from the outset that the present concern of this article is not with the merits of the court's decision. In other words, the article is not concerned with the question whether or not that decision was wrong. This could come in the future. Positively stated, this article is concerned with the propriety of the various reactions to the judicial verdict in the Efstathiou case-especially the reactions of the Attorney-General of the Republic of Cyprus, the President of the Republic of Cyprus, members of the legal profession in Cyprus (lawyers), and the Supreme Court of Cyprus. More specifically, this article is concerned with some of the issues raised by the various reactions as adumbrated above.

From available sources, the Attorney-General of the Republic of Cyprus (the Chief Legal Officer of the State of Cyprus ${ }^{6}$ ) was so furious about the verdict that he attempted to interrupt the judges while reading their judgment, but was refused. ${ }^{7}$ Thereafter, he issued a press statement condemning the verdict thus: 'The Criminal Court's decision is wrong, from start to finish, and unfortunately it has harmed the prestige of the judicial system irreversibly... We can't always trust court decisions; each civilian has the right to judge them for themselves. ${ }^{8} \mathrm{He}$ rejected the reasoning of the judges that the media's projection of the case amounted to trial by media and affected the rights of the accused persons to fairhearing: 'In such a matter of importance and public interest, don't the media have the right to show scenes and make comments? ... The media did their jobs well and not only did they have the right, they had an obligation to inform the public'. ${ }^{9}$ He also appeared on

5 In Constantinides v. Vima Ltd [at p. 355], the Supreme Court of Cyprus noted that ' $[\mathrm{t}] \mathrm{he}$ administration of justice in Cyprus is modelled on the administration of justice under the common law judicial system...'

6 The office of the Attorney-General is one of the independent offices established under Part 6 of the Constitution of Cyprus 1960. Holders of the office enjoy security of tenure as a judge of the High court.

7 Theodoulou, J.: AG: Court decision wrong from start to finish [CyprusMail (Internet Edition), 21 March 2009].

8 Ibid.

9 Ibid. 
television programme, condemning the judicial verdict in very strong terms. ${ }^{10} \mathrm{~A}$ former Deputy Attorney-General of Cyprus and former Cypriot Judge of the European Court of Human Rights, Loukis Loucaides, agreed with the position of the Attorney-General. He also launched a serious attack on the judges thus: 'There is something wrong with the way the judges approached the evidence. They may be not sufficiently trained...'. ${ }^{11}$ Moreover, with a seeming tang of incontrovertible authority, he declared: 'The media influence is irrelevant to the proceedings, yet the court went out of its way to touch on the matter. ECHR [European Court of Human Rights] case law is clear on this. In the cases of professional judges (with no jury), the issue of media influence does not arise.'. ${ }^{12}$

On his part, the President of the Republic of Cyprus expressed surprise at the decision, stating that it was a 'provocation to the sense of justice of every citizen of the Republic'. ${ }^{13}$ Importantly, he also expressed his respect for the independence of the judiciary.

Further reactions, as indicated above, came from members of the legal profession and the Supreme Court. Speaking on behalf of the Cyprus Bar Association, its President, Doros Ioannides, cautioned against making public statements 'when a decision is under appeal' ${ }^{14} \mathrm{He}$ insisted on the need to respect the integrity of the courts, arguing: 'Statements and counterstatements ... will not help justice. Cyprus justice has helped this country and under no circumstances should we try to diminish its role'. ${ }^{15}$ On the contrary, the President of the Limassol Bar Association (Limassol Branch of the Cyprus Bar Association), Christos Melides, argues that lawyers, the general public and the media 'have the right to criticize the decision and make statements on the subject'; ${ }^{16}$ for him, this is part of the freedom of expression or the right to free speech. ${ }^{17}$ It should be mentioned that on this position he is in tandem with a large section of the Cypriot society, including (particularly) the gentlemen of the press.

Lastly, the Supreme Court of Cyprus-reacting directly to the caustic public 'criticisms' of the Assize Court judges and the Cypriot judiciary by the Attorney-General-said in a public statement that it was shocked and discontented with the 'inappropriate statements of the Attorney-General to the media'. ${ }^{18}$ The statement continued: 'The Attorney-General should be better aware of the fact that if he disagrees with a decision, the legal means he has at his disposal is to appeal, and not attack the courts and justice system through television... The Supreme Court condemns without reservations the televised attempts to diminish the prestige of the judicial system.... ${ }^{19}$

10 See: What sort of example are our justice officials setting? [CyprusMail (Internet Edition), 27 March 2009] See also the view of Hazou, E. contained in Pissa, M.: Banana republic - rejoice in your justice system [CyprusMail (Internet Edition), 20 March 2009].

11 See Evripidou, S.: Former European Court of Human Rights Judge says cops acquittal "stupid and absurd" [CyprusMail (Internet Edition), 22 March 2009].

12 Ibid (emphasis added).

13 See Theodoulou: AG: Court decision... op. cit.

14 Theodoulou, J.: Black page in the history of Cypriot justice. [CyprusMail (Internet Edition), 21 March 2009],

15 Ibid.

${ }^{16}$ Hassapi, A.: Limassol Bar Association speaks out against court decision acquitting police officers [CyprusMail (Internet Edition, 25 March 2009].

17 Ibid.

18 Theodoulou: $A G$ : Court decision ... op. cit. See also Theodoulou: Black page in the history... op. cit.

$19 \mathrm{Ibid}$ 
Interestingly, the recent development in Cyprus recalls similar incidents around the world: riots following acquittal on criminal charges. Two examples will suffice to illustrate this point. First, in 1992 the acquittal of the four policemen charged in California v. Powell et al. with the beating of Rodney King 'unleashed the rage of many in L.A. [Los Angeles]'; ${ }^{20}$ it caused terrible rioting. In a cruel coincidence, that incident, like the recent one in Cyprus, was caught on video when it occurred in 1991. The second example is Jessica Lal case that caused serious protests and riots in India in 1998. In fact, such was the impact of the riots that the government of India was forced to order a retrial of the case. ${ }^{21}$ Importantly, both of these incidents, like the present Efstathiou case in Cyprus, raised the questions of trial by media and fair trial.

\section{Analysis/Critique}

From all the foregoing public reactions, it is clear that issues of judicial independence, trial by media and fair trial have been raised, among others. This article will attempt to briefly address the specifically mentioned issues here. For convenience and clarity, these issues will be addressed in two sub-sections. The first sub-section will address the issue of independence of the judiciary while the succeeding sub-section will deal with the issue of trial by media and fair trial as well as the closely related issue of contempt of court.

\section{1. Independence of the Judiciary ${ }^{22}$}

Judges individually shall be free, and it shall be their duty, to decide matters before them impartially, in accordance with their assessment of the facts and their understanding of the law without any restrictions, influences, inducements, pressures, threats or interferences, direct or indirect, from any quarter or for any reason. ${ }^{23}$

20 Cannon, L.: Rodney King's Legacy. <http://www.courttv.com/archive/casefiles/rodneyking/> (accessed 27 April 2009).

21 Samanta, N.: Trial by Media - Jessica Lal Case. <http://ssrn.com/abstract=1003644> (accessed 22 April 2009).

22 There is a large body of literature on the concept of independence of the judiciary in relation to both national and international-regional courts and tribunals. See, by example, Bradley, A.W.-Ewing, K. D.: Constitutional and Administrative Law, 14 ${ }^{\text {th }}$ ed. Essex 2007, 388-395; Kirby, M.: A global approach to judicial independence and integrity, University of Queensland Law Journal 21/2 (2001) 147-159; Larkins, C. M.: Judicial independence and Democratization, American Journal of Comparative Law, 44 (1996) 605-626; Mackenzie, R.-Sands, P.: International courts and tribunals and the independence of the international judge. Harvard International Law Journal, 44 (2003) 271-285; Olbourne, B.: Independence and Impartiality: International Standards for National Judges and Courts. The Law \& Practice of International Courts and Tribunals, 2 (2003) 97-126; Claus, L.: Constitutional Guarantees of the Judiciary: Jurisdiction, Tenure, and Beyond. American Journal of Comparative Law, 64 (2006) 459-483; Lord Hope of Craighead: Judicial Independence. Scots Law Times, 13 (2003) 105-111; Plaxton, M.: The Neutrality Thesis and the Rothstein Hearing. University of New Brunswick Law Journal, 58 (2008) 92-104.

23 Article 2:02 of the Universal Declaration on the Independence of Justice (the 'Montreal Declaration'); quoted in Olowofoyeku, A. A.: Suing Judges: A Study of Judicial Immunity. Oxford, 1993, 1. The author explained the importance of this international instrument thus: 'The declaration was adopted at the first plenary session of the $1^{\text {st }}$ World Conference on the Independence of Justice which was held at Montreal on 10 June 1983. It was [and still is] a universal statement of principle. It stated the independence which "national judges" ought to enjoy.' Ibid. More recently, Article 1 of the Uni- 
As a concept, independence of the judiciary (or judicial independence) is wellunderstood in most, if not all, parts of the world and has been defined or described by various authors ${ }^{24}$ as well as in various national and international instruments, including the UN Basic Principles on the Independence of the Judiciary $1985,{ }^{25}$ the Latimer House Guidelines on Parliamentary Sovereignty and Judicial Independence 1998, and the Cairo Declaration on Judicial independence 2003. For present purposes, it is sufficient to refer to only two descriptions/definitions of the concept. According to Chris Maina Peter:

Independence of the judiciary means [that] every judge or magistrate, as the case may be, is free to decide matters brought before him in accordance with his assessment of the facts and his understanding of the law without any improper influence, inducements, or pressures direct or indirect from any quarter or for any reason. There is a tendency of thinking that independence of the judiciary means just independence from the legislature and executive. In reality it means more than that. It also means independence from political influence whether exerted by the political organ of the State, or by political parties, or the general public... ${ }^{26}$ (emphasis added).

Importantly, the above statement echoes the provision of Article 2 of the UN Basic Principles on the Independence of the Judiciary 1985, which states that 'the judiciary shall decide matters before them impartially, on the basis of facts and in accordance with the law, without any restrictions, improper influences, inducements, pressures, threats or interferences, direct or indirect, from any quarter or for any reason'. Based on this, it is important to underline that judicial decisions are based on facts placed before the court and the extant law (lex lata), and not on de lege ferenda (the law as it ought to be).

versal Charter of the Judge 1999 provides that 'the independence of the judge is indispensable to impartial justice under the law. It is indivisible. All institutions and authorities, whether national or international, must respect, protect and defend that independence'. More importantly, Article 2 thereof provides, inter alia, that '...The Judge, as a holder of judicial office, must be able to exercise judicial powers free from social, economic and political pressure...' The Charter was adopted at the meeting of the Central Council of the International Association of Judges in Taipei (Taiwan) on 17 November 1999. See further Recommendation No. R (94) 12 (on the independence, efficiency and role of Judges)-adopted by the Committee of Ministers of the Council of Europe on 13 October 1994, esp. Principle 1; European Charter on the Statute for Judges (adopted at a multilateral meeting held 8-10 July 1998 in Strasbourg, under the auspices of the Council of Europe).

24 See Canivet, G.-Andenas, M.-Fairgrieve, D. (eds.): Independence, Accountability, and the Judiciary. London, 2006.

25 Adopted by the Seventh United Nations Congress on the Prevention of Crime and the Treatment of Offenders held at Milan from 26 August to 6 September 1985 and endorsed by General Assembly resolutions 40/32 of 29 November 1985 and 40/146 of 13 December 1985.

26 Peter, C. M.: Independence of the Judiciary in Tanzania: Many Rivers to Cross. In: Jjuuko, W. F. (ed.): The Independence of the Judiciary and the Rule of Law: Strengthening Constitutional Activism in East Africa. Kampala, 2005, 58. See also the speech of the Chief Justice of South Africa, Mohamed C. J.: The Role of the Judiciary in a Constitutional State, South Africa Law Journal, (1998) 111, at 112-113: 'What judicial independence means in principle is simply the right and the duty of judges to perform the function of judicial adjudication, through an application of their own integrity and the law, without any actual or perceived, direct or indirect interference from or dependence on any other person or institution...' The speech was given at the occasion of the first orientation course for newly appointed judges in South Africa. 
In summary, one can say that independence of the judiciary essentially requires that judges should be free to decide cases brought before them without fear of any reprisal against them. This ensures that they dispense justice fairly, impartially and without fear or favour. To be sure, the impartial dispensation of justice is in the interest of the society in general. As the Kenyan Section of the International Commission of Jurists (KSICJ) explains, 'the judiciary is the guardian of the rights of man and it protects the rights from all possibilities of individual and public encroachments' ${ }^{27}$ (One critical question raised in the recent Cypriot case under consideration here is whether the judiciary has failed in its constitutional role, but this is beyond the scope of the present article). This is why most, if not all countries of the world, institute constitutional, statutory and other measures to ensure the independence of the judiciary, including the concept of judicial immunity which insulates judges from legal (civil and criminal) actions based on what they said or did in the course of judicial proceedings. At the international level, Article 2: 24 of the Universal Declaration on the Independence of Justice (the 'Montreal Declaration') 1983 provides that 'Judges shall enjoy immunity from suit, or harassment, for acts and omissions in their official capacity'. Furthermore, the 1985 UN instrument on the independence of the judiciary enjoins States to guarantee the independence of the judiciary and enshrine it in the Constitution or the law of the country. ${ }^{28}$ On the aspect of judicial immunity at the national level, Olowofoyeku has explained the general position in the common-law world as follows: ${ }^{29}$

Judges are not free from error and some do not always take good care. The errors or lack of due care may, if and when they occur, have disastrous consequences for a litigant. The problem is the correct course of action when such a situation occurs. Various legal systems have developed their own ways of coping with the problem. The common-law world [including Cyprus] has generally adopted a rather benign approach than stoning the judges-it has shrouded them in an almost impregnable protective cloak. A judge could go to sleep during trial, spend four years in reaching a decision, be slanderous, and yet anyone aggrieved by his behaviour will usually have no recourse. This is known as absolute immunity. ${ }^{30}$

This is consistent with the exposition of Lord Denning in his speech in Sirros v. Moore, ${ }^{31}$ thus:

Ever since the year 1613, if not before, it has been accepted in our law that no action is maintainable against a judge for anything said or done by him in the exercise of a jurisdiction which belongs to him. The words which he speaks are protected by an

27 Kenyan Section of the International Commission of Jurists, Best Practice Guide for Judicial Independence. Nairobi, 2007.

28 Article 1.

29 Olowofoyeku: op. cit. 2.

30 The author referred to relevant material drawn from common-law countries such as the U.K, U.S., New Zealand and Nigeria. Note that this author believes that the common law position needs reconsideration, especially in contemporary times. See Olowofoyeku, A. A.: Accountability versus Independence: The Impact of Judicial Immunity. In: Canivet-Andenas-Fairgrieve (eds.): op. cit. 357, esp. at 383 .

31 Sirros v. Moore [1975] Queen's Bench, 118. Note that the common law position re-stated by Lord Denning is reinforced by section 2(5) of the Crown Proceedings Act 1947 which absolves the Crown of any liability for any person discharging judicial or quasi-judicial functions. 
absolute privilege. The orders which he gives, and the sentences which he imposes, cannot be made the subject of civil proceedings against him. No matter that the judge was under some gross error or ignorance, or was actuated by envy, hatred and malice, and all uncharitableness, he is not liable to an action. The remedy of the party aggrieved is to appeal to a Court of Appeal or to apply for habeas corpus, or a writ of error or certiorari, or take some such step to reverse his ruling... The reason is not because the judge has any privilege to make mistakes or to do wrong. It is so that he should be able to do his duty with complete independence and free from fear. It was well stated by Lord Tenterden C.J. in Garnett v. Ferrand (1827) 6 B. \& C. 611, 625: "This freedom from action and question at the suit of an individual is given by the law to the judges, not so much for their own sake as for the sake of the public, and for the advancement of justice, that being free from actions, they may be free in thought and independent in judgment, as all who are to administer justice ought to be". ${ }^{32}$

With specific regard to Cyprus, it is important to note that the principle of judicial immunity is given expression in Articles 133(10) and 154(10) of the Constitution of Cyprus 1960 which provides that no action shall be brought against the President of the Supreme Court or the High Court or any other judge of the Supreme Court or the High Court for any act done or words spoken in his judicial capacity. The independence of the Cypriot judiciary is further guaranteed by other means, including: (1) the mode of appointment (designed to prevent executive or other institutional influence ${ }^{33}$ ); (2) security of salary (a judge's remuneration cannot be altered to his disadvantage after his appointment ${ }^{34}$ and constitutes a charge on the consolidated fund ${ }^{35}$ ); (3) security of tenure (once appointed, a judge cannot be removed until he/she attains the retirement age of 68 years, except for misconduct determined by an independent Council established under the Constitution ${ }^{36}$ ). In fact, in a recent report on the state of human rights in Cyprus it was acknowledged that the Cypriot judiciary is independent. ${ }^{37}$

It is important to emphasize that the judicial immunity enjoyed by judges 'applies to both civil and criminal liability, and protests judges in respect of acts of a judicial nature'. ${ }^{38}$ While the principle of judicial immunity do not purport to insulate judges against public

32 Sirros v. Moore [at p. 132]. See also Fray v. Blackburn (1863) 122 ER 217, where Crompton J. said: 'It is a principle of our law that no action will lie against a judge of one of the superior courts [as well as inferior courts and persons presiding over quasi-judicial bodies] for a judicial act, though it be alleged to have been done maliciously and corruptly... The public are deeply interested in this rule, which, indeed exists for their benefit, and was established in order to secure the independence of judges'. See further Scott v. Stansfield (1868) LR 3 Ex 220, 223 per Kelly CB.

33 See generally Constitution of Cyprus, Articles 133 and 153.

34 Articles 133(12) and 153(12).

35 Article 166(1)(b).

36 See Constitution of Cyprus, Articles 133(7) \& (8) and 153(7) \& (8). The retirement age of first instance judges is 63 years. See Courts of Justice Law 14/60 (as amended), section 8(2). See also Constitution of Cyprus, Article 158(3).

37 US Department of State, 2008 Human Rights Report: Cyprus (Washington, DC 2009) section 1(e), <http://www.state.gov/g/drl/rls/hrrpt/2008/eur/119074.htm> (accessed 23 April 2009).

38 Olowofoyeku: op . cit. 77 . However, with regard to criminal liability, the immunity is not absolute. See Ibid. 76. 
criticisms ${ }^{39}$ it is contended that certain kinds of public criticism-especially by certain responsible and highly-placed persons in the society (such as high officers of government and lawyers)-could amount to intimidation or political pressure and, more seriously, have the capacity to instill fear in judges ${ }^{40}$ apart from their potential to undermine public confidence in the judiciary and/or lower the integrity and prestige of the courts in the eyes of the people. When this happens, the hallowed independence of the judiciary (or 'independence of justice', as the 1983 Montreal Declaration calls it $)^{41}$ is compromised, to the detriment of the judicial system and the society in general. This appears to be the present situation in Cyprus as a result of the high-profile criticisms of the judiciary by the President of the Republic of Cyprus, the Attorney-General of the Republic Cyprus and senior Cypriot lawyers, inter alia, following the decision of the Nicosia Assize Court to acquit the ten policemen charged with assaulting two young Cypriot students. ${ }^{42}$

In Britain, the need to preserve and protect the independence of the judiciary explains the existence of the British constitutional convention which forbids members of Parliament from asking Ministers questions which border on the criticism of judges in the Parliament. ${ }^{43}$ This is also why British Ministers generally refrain from criticizing judges publicly, though instances of such criticisms can be pointed to. ${ }^{44}$ It is possible that the President of the Cyprus Bar Association had this approach in mind when he issued the statement earlier stated above. Arguably, the British approach reflects the acceptable approach in the Republic of Cyprus as it is consistent with the general approach within the commonwealth. Viewed this way, it is submitted that the reaction of the Attorney-General of Cyprus (as briefly stated above) was unrestrained, precipitate, and against the spirit of independence of the judiciary, and probably unprofessional. Similar comments could apply to the reaction of the President of the Republic, but it is important to note that he recognized that his criticism might impinge on the independence of the judiciary and declared his respect for it. Importantly, the President's recognition of the independence of the judiciary is in line with Article 2: 04 of the 1983 Montreal Declaration which states that 'the judiciary shall be independent of the executive and the legislature'.

All in all, there is no gain-saying that the independence of the judiciary is important and indispensable in all democratic countries. In this context, Olowofoyeku has rightly stated:

39 See The Role of the Judge in Contemporary Society, United Nations Crime and Justice Research Institute (UNICRI) Publication No 24, 1984, where it was stated: 'Independence does not, however, mean absence of responsibility for his own actions. The concept which regards the judge as unrestrained by law (legibus solitus) would end, sooner or later, in protecting not so much his necessary freedom, as the arbitrariness of his decisions'. Ibid. 20.

40 Bradley and Ewing note that 'judicial independence requires that judges should be protected from political pressure to reach decisions which suit the government or other powerful interests' See Bradley-Ewing: op. cit. 390.

41 For a recent and interesting discussions and debate on the independence of the judiciary in some parts of the world, see Canivet-Andenas-Fairgrieve (eds.): op. cit.

42 Compare Addo, M. K.: Freedom of Expression and the Criticism of Judges: A Comparative Study of European Legal Standards. Dartmouth, 2000; Comella, F.: Freedom of Expression in Political Contexts: Some Reflections on the Case Law of the European Court of Human Rights. In: Wojciech Sadurski (ed.): Political Rights Under Stress in 21 $1^{\text {st }}$ Century Europe. Oxford, 2006, 116.

43 See Barnett, H.: Constitutional \& Administrative Law., $7^{\text {th }}$ ed. Oxford, 2009, 388.

44 See Bradley-Ewing: op. cit. 390-391. 
In a publication released jointly by the International Association of Judges and the United Nations Social Defence Research Institution, ${ }^{45}$ judicial independence was seen as an essential prerequisite for guaranteeing all the basic rights and freedoms acknowledged by modern civilized society. As such, the legal system [of all countries of the world, especially common law countries such as Cyprus] must protect such independence against any encroachment by other powers, and must clearly provide the means to defend the judge against all abuses and pressures from individuals or groups. ${ }^{46}$

The next question is whether the Supreme Court of Cyprus was right to issue a public response to the reaction of the Attorney-General. This is not an easy question which could be answered simply by 'yes' or 'no'. Going by English experience, and this is by no means a universal one, judges hardly respond to press criticisms. In an annual lecture of the Judicial Studies Board entitled 'Judicial Independence', delivered on 5 November 1996, Lord Bingham suggested that judges should be 'thick-skinned' enough to ignore press comments or criticisms ${ }^{47}$ On this view, judges should refrain from personal response to criticisms. This was also the view expressed by Lord Denning in $R$. v. Metropolitan Police Commissioner, Ex parte Blackburn ${ }^{48}$ and the European Court of Human Rights (ECtHR) in the Case of Prager and Oberschlick v. Austria. ${ }^{49}$ Yet, it has been asked, 'if the judge decides not to respond, who is to speak on behalf of the judiciary? ${ }^{50}$ Perhaps, this should be left for a Minister-particularly the Minister in charge of the Department of Justice, as in the U.K. ${ }^{51}$ In fact, section 3 of the Constitutional Reform Act 2005 imposes a duty on the Lord Chancellor (i.e. U.K Minister of Justice) to uphold the continued independence of the judiciary. ${ }^{52}$ Even so, it has also been forcefully and rightly argued that 'where necessary, an independent judiciary should be defending itself' ${ }^{53}$ An exemplary occasion, it has been suggested, is when a judge suffers a well-publicized and personal attack by a journalist of considerable seniority and influence. ${ }^{54}$ It is submitted that caustic and sustained criticisms

45 See UNICRI publication.

46 Olowofoyeku: op. cit. 1-2.

47 Bingham, T.: The Business of Judging. Oxford, 2000, 61-62. The expression "thick-skinned" enough to ignore press comments' was a summary made by Alisdair Gillespie. See Gillespie, A.: The English Legal System. Oxford, 2007, 205.

48 R. v. Metropolitan Police Commissioner, Ex parte Blackburn [1968] 2 All England Law Reports, 319, at 320. ('Those who comment can deal faithfully with all that is done in a court of justice. They can say we are mistaken, and our decisions erroneous, whether they are subject to appeal or not. All we would ask is that those who criticize us will remember that, from the nature of our office, we cannot reply to their criticisms.')

49 Case of Prager and Oberschlick v. Austria, Judgment of 26 April 1995, Series A vol. 313, para. 34 ('...judges who have been criticized are subject to a duty of discretion that precludes them from replying').

50 Pannick, D.: Should judges respond to criticism? (The Times, 27 November 2008).

51 See Gillespie: The English Legal System. op. cit. 206-207.

52 The duty extends to other Ministers (including the Prime Minister) and 'all with responsibility for matters relating to the judiciary or administration of justice'. Ibid. This may be regarded as a codification of a long-standing constitutional convention. See further Article 6 of the European Convention on Human Rights (made applicable domestically in the U.K by the Human Rights Act 1998).

53 See Pannick: Should judges respond... op. cit. Lord Pannick, QC is one of the top 10 most influential UK lawyers. See 'The Times Law 100 2009' (The Times, 23 July 2009).

54 Ibid. 
by an Attorney-General, senior lawyers and/or other influential members of the society would qualify as such occasion. Hence, the Supreme Court of Cyprus was arguably right to have issued a statement in response to the avowed criticism by the Cypriot Attorney-General of the recent decision of the Nicosia Assize Court. Surely, it is respectfully submitted, the reaction of the Cypriot Attorney-General and other senior lawyers, more than that of the society in general, greatly damaged the legal profession and the integrity and prestige of the courts, judges and the entire Cypriot judicial system.

In 2008, the British Judicial Communications Office issued a brief written statement in response to a critical media statement of the Editor of Daily Mail against a judge. ${ }^{55}$ The then Lord Chancellor, Lord Falconer of Thoroton, also gave an interview defending judicial independence. Importantly, the House of Lords Select Committee on the Constitution approves and encourages this approach. There are also instances in Britain when judges had felt able to defend themselves from public criticisms by sending their response as a letter to the press. ${ }^{56}$ Interestingly, the response of the Supreme Court of Cyprus is in line with the approach of Lord Chancellor Lord Irvine of Lairg in 2003 in response to the criticism of judges by the Home Secretary. He said: 'Maturity requires that when you get a decision that favours you, you do not clap. And when you get one that goes against you, you do not boo' ${ }^{57}$ The Supreme Court of Cyprus said much the same when it suggested that in attacking the judges/judiciary the Attorney-General of Cyprus had lost his 'self-control'. ${ }^{58}$

\subsection{Trial by Media versus Fair Trial ${ }^{59}$}

"Trial by newspaper," like all catch phrases, may be loosely used, but it summarizes an evil influence upon the administration of criminal justice... ${ }^{60}$

Another important issue that arose in the Efstathiou case was whether the media publicity of the unfortunate incident compromised fair trial in the case. ${ }^{61}$ The trial court stated in its judgment that the media coverage of the alleged criminal act (before and during the proceedings) ${ }^{62}$ 'constituted serious interference in the course of justice and pre-empted the outcome of the trial' ${ }^{63}$ and that 'it constitutes a usurpation of the judicial authority and contempt of court' ${ }^{64}$ However, it has been doubted whether the media publications really affected the outcome of the case; if it did, it has been argued, the outcome of the case would

55 Ibid.

56 Ibid.

57 Ibid.

58 See Theodoulou: Black page in the history... op. cit.

59 See generally, Law Commission of India: $200^{\text {th }}$ Report on Trial by Media: Free Speech and Fair Trial under Criminal Procedure Code, 1973. New Delhi, 2006; available at: $<$ http://lawcommissionofindia.nic.in/reports/rep200.pdf > (accessed 27 April 2009); Eady, D.-Eady, A.-Smith: On Contempt, $3^{\text {rd }}$ ed., London, 2005; Bonnington, A. J.-McInnes, R.-McKain, B.: Scots Law for Journalists $7^{\text {th }}$ ed., Edinburgh, 2000.

60 Per Justice Frankfurter in Pennekamp v. Florida, 328 U.S. 331 (1946), at 351.

61 The Supreme Court of Cyprus condemned 'trial through the press' in Constantinides v. Vima Ltd., [at p. 359].

62 By the judges' count, the number of articles written in relation to the case amounted to 361 . See Charalambous, L. Police acquittal sets an eerie precedent for Helios trial [CyprusMail (Internet Edition), 29 March 2009].

${ }^{63}$ Reproduced in Evripidou: Former European Court of Human Rights Judge... op. cit.

64 Ibid. 
have been different. ${ }^{65}$ Even so, it must be recognized that 'the principle of the independence of the judiciary entitles and requires the judiciary to ensure that judicial proceedings are conducted fairly and that the rights of the parties are respected' ${ }^{66}$ Burges has succinctly explained the difference between 'trial by media' and 'fair trial', when he said: ${ }^{67}$

[T] rial by media by its very nature detracts from the notions of what the law describes as a fair trial. That is a trial free from prejudice. A trial where jurors [and judges] already have preconceived notions of the guilt or innocence of the accused can hardly be said to be "a fair and impartial trial" as defined in The King v. MacFarlane, ex parte O'Flanaghan and O'Kelly (1923) 32 CLR 518, 541-542.

The evil of trial by media was also disapproved in Attorney-General v. English ${ }^{68}$ Lord Diplock explained that the public policy that underlies the strict liability rule established under section 1 of the English Contempt of Court Act 1981 is 'deterrence'. He then declared:

Trial by newspaper or, as it should be more compendiously expressed today, trial by media, is not to be permitted in this country [U.K and, indeed, elsewhere in the world]. That the risk that was created by the publication when it was actually published does not ultimately affect the outcome of the proceedings is, as Lord Goddard C.J. said in Reg. v. Evening Standard Co. Ltd. [1954] 1 Q.B. 578, 582, "neither here nor there..." ${ }^{\circ 9}$

Under the Cypriot legal system, as is the case in all common law countries, an accused person is presumed innocent until he has been found guilty in a judicial proceeding. Article 12(4) of the Constitution of Cyprus 1960 is categorical on this: 'Every person charged with an offence shall be presumed innocent until proved guilty according to law' ${ }^{70}$ The problem with media reporting of criminal acts or pending cases is that it often tends to find the accused guilty before trial or conclusion of trial, contrary to the requirements of fair hearing. ${ }^{71}$ As Naylor categorically states, 'it is clear that some media reporting poses a threat to the fair trial of the defendant' ${ }^{72}$ In the same way, the Media Institute of Kenya has frankly admitted that 'in the coverage of court proceedings by the press, there are cases where such coverage can imperil the administration of justice' ${ }^{73}$ Hence, the law of contempt of court is meant to deter the potential effect of publications on an accused's right to fair

65 Ibid (per Loucaides: 'if the media really had influenced opinion then the judges would not have acquitted the ten officers').

66 UN Basic Principles on the Independence of the Judiciary 1985, Article 6.

67 Burgess, C.: Can "Dr Death" Receive a fair Trial? OUT Law \& Justice Journal, (2007), 2; available at: < http://www.austlii.edu.au/au/journals/QUTLJJ/2007/2.html > (accessed 24 April 2009).

68 Attorney-General v. English [1983] 1 Appeal Cases, 116.

69 Ibid. 141.

70 This is exactly the provision of Article 6(2) of the European Convention on Human Rights 1950.

71 This is not to suggest that issues of public interest should not be reported or discussed; far from that. What is objectionable is the tendency to interfere with judicial proceedings or find an accused person guilty on the pages of a newspaper.

72 Naylor, B.: Fair Trial or Free Press: Legal Responses to Media Reports of Criminal Trials, Cambridge Law Journal, 53 (1994) 492, at 501.

73 Makali, D. et. al: Fair Trial and the Freedom of the Press. In Makali, D. (ed.): Media Law and Practice: The Kenyan Jurisprudence. Nairobi, 2003. 
and impartial trial as well as to protect the honour and integrity of courts of law. As adumbrated above, section 1 of the English Contempt of Court Act $1981^{74}$ establishes 'strict liability rule' for contempt of court cases - defined to mean 'the rule of law whereby conduct may be treated as a contempt of court as tending to interfere with the course of justice in particular legal proceedings regardless of intent to do so'. According to section 2(2) thereof, this rule applies only to 'a publication which creates a substantial risk that the course of justice in the proceedings in question will be seriously impeded or prejudiced'.$^{75}$ Importantly, the rule applies only if the proceedings in question are 'active ${ }^{76}$ as explained in the Act: for example, from arrest with or without warrant to the conclusion of the case - say by acquittal or sentence. ${ }^{77}$

In Cyprus, the law of contempt of court is contained in the Courts of Justice Law $14 / 60^{78}$ (as recently amended by the Courts of Justice (Amendment) Law 36(1)/2009). ${ }^{79}$ Article 44(1) thereof provides in part, as follows: ${ }^{80}$

Any person who,

a) within the premises in which any judicial proceeding is being had or taken, or within the precincts of the same, shows disrespect, in speech or manner, of or with reference to such proceeding or any person before whom such proceeding is being had or taken,$^{81}$ or

b) causes an obstruction or disturbance in the course of a judicial proceeding, or

c) while a judicial proceeding is pending...publishes any writing, makes any speech, or does any act misrepresenting such proceeding or is capable of prejudicing the fair trial of such

74 Revised Laws of the UK, Cap 49.

75 See generally, Miller, C. J.: Contempt of Court, $2^{\text {nd }}$ ed., Oxford, 1990, Chapter 10. The law of contempt of court in England can partly be found in the common law.

76 Contempt of Court Act 1981, section 2(3).

77 Contempt of Court Act 1981, section 2(4) and schedule 1. This provision is based on the leading case of Hall v. Associated Newspaper (1978) SLT 241 (Scotland).

78 This provision is largely based on Article 49 of the previous Cap. 8. Note that the law of contempt of court in Cyprus was made pursuant to Article 162 of the Constitution of Cyprus 1960. Furthermore, Articles 150 and 162 of the Constitution give the Supreme Court and the High Court respectively power to punish for contempt of itself.

79 The law was earlier amended by Law 166/1987. The amendment effected by Law 36(1)/2009 was principally designed to bring the procedural aspects of contempt in the face of the court in Cyprus in line with the decision of the European Court of Human Rights in Kyprianou $v$ Cyprus (App No. 73797/01) ECHR, Judgment of 27 January 2004. Essentially, while Cypriot courts still have the power to punish for contempt committed in the face of the court, if the act constituting the contempt 'turn against the person of the judge' (i.e. directed at the judge personally) he cannot adjudicate the matter personally but has to refer the matter to the President of the Supreme Court who may appoint another judge to adjudicate the matter. See Law 14/60 (as amended by Law 36(1)/2009), Article 44 paras $2-10$. The idea is to prevent an affected judge being a judge in his own cause, in breach of the right to fair trial under Article 6 of the European Convention on Human Rights.

${ }^{80}$ I am grateful to my colleague, Dr Achilles Emilianides, for drawing my attention to the recent amendment of Law 14/60 by Law 36(1)/2009. Moreover, I am grateful to him for translating the original Greek text of Law 36(1)/2009 into English for my convenience and for his useful comments on the draft of this article. Furthermore, I would also like to acknowledge the assistance of another colleague, Nicolas Angelides, who translated other Greek texts into English for me. However, I accept sole responsibility for any errors found in this article.

81 See Mantis v. The Police, Cyprus Law Reports, (1979) 125; Evangelou v. Police (No. 2) Cyprus Law Reports (2000) 224 (in Greek). 
proceeding or of interrupting or delaying the course of justice or calculated to lower the authority of any person before whom such proceeding is being had or taken, or

d) publishes a report of the evidence taken in any judicial proceeding at which, under this Law or any other Law for the time being in force, only the parties and their advocates or other representatives, if any, and the officers of the Court are permitted to be present, or

e) publishes any writing, makes any speech or does any act containing scandalous matter respecting any Court which has adjudicated in any proceeding relating to any judicial proceeding, ...

is guilty of a misdemeanour and is liable to imprisonment up to six months or to a fine not exceeding $450 \mathrm{CP}$ [450 Cyprus Pounds (£CY450)] or to both sentences. ${ }^{82}$

It is important to point out that the requirement of English law that to constitute contempt of court the criminal proceeding in question must be 'active' is generally the same as the requirement that the judicial proceeding be 'pending' under Cypriot law-i.e. from the time of arrest ${ }^{83}$ to the conclusion of the case. This is also the position in Nigerian law, ${ }^{84}$ as noted extra-judicially by Justice Alabi: ${ }^{85}$ 'A criminal prosecution may be said to be pending.... at any time after a person has been arrested and is in custody. It is not necessary that the accused person should have been committed for trial; nor is it necessary that he should have been brought before a court of summary jurisdiction' ${ }^{86}$ Importantly, the same position holds in other common-law/commonwealth countries. For example, in AK Gopalan v. Noordeen ${ }^{87}$ the Indian Supreme Court held that a publication made after the 'arrest' of a person could be contempt if it was prejudicial to the suspect or accused.

In fact, under the common law it is also contempt of court to publish prejudicial material about a criminal case when criminal proceedings are 'imminent' ${ }^{88}$ Note that the

82 Since 1 January 2008 Cyprus has adopted the Euro as its national currency. The sum of $£ C Y 450$ is now approximately $€ 765$ (seven hundred and sixty-five Euros).

83 This is consistent with the 24-hour rule under Article 11(5) of the 1960 Constitution of Cyprus: A 'person arrested shall, as soon as is practicable after his arrest, and in any event not later than twenty-four hours after the arrest, be brought before a judge, if not earlier released'. According to Hall's case, once a person is arrested he comes within the 'care and protection' of the court, as he has to be produced in court within 24 hours. In his introduction to the $200^{\text {th }}$ Report of the Law [Reform] Commission of India, the Chairman, Justice M.J. Rao, explains that: 'The reason for fixing arrest as the starting point is that, if a publication is made after arrest referring to the person's character, previous conviction or confessions etc., the person's case will be prejudiced even in bail proceedings when issues arise as to whether bail is to be granted or refused, or as to what conditions are to be imposed and whether there should be police remand or judicial remand. Such publications may also affect the trial when it takes place later'. See Law Commission of India: op cit.

${ }^{84}$ See generally, Fawehinmi, G.: The Law of Contempt in Nigeria (Case Book). Lagos, 1980.

85 Justice Alabi, A. A. was sometime the Chief Judge of Lagos State, Nigeria.

86 Alabi, A.A.: Contempt of Court and the Sub-Judice Rule. In Oyeyipo, T.A.-Gummi, L. H.Umezulike, I. A. (eds.): Judicial Integrity, Independence and Reforms: Essays in Honour of Hon. Justice M.L Uwais. Enugu, 2006, 181, at 183.

87 A. K. Gopalan v. Noordeen (1969) 2 Supreme Court of Cases, 734.

88 Ibid. See also Rex v. Parke (1903) 2 KB 432, at 437-438; $R$ v. Savundranayagan, All England Law Reports (1968), 439, 441; Attorney-General v. News Group Newspapers plc [1989] QB 110, at 125 and 130 (per Watkins LJ); R. v. Horsham Justices (1982) 2 QB 762 (dealing with the term 'imminent' in the 1981 Act, section 4(2)). Cf. R. v. Clarke, ex parte Crippen [1910] 27 TLR 32; James v. Robinson (1963) 109 Commonwealth Law Reports, 593 (High Court of Australia). Note that the English Contempt of Court Act 1981 only amended, and did not abolish, the common law of contempt of court. 
contempt committed when a judicial proceeding is 'pending' or 'active' is known as sub judice contempt. Importantly, as can be gleaned from the provisions of Article 44 of Law $14 / 60$ (as amended by Law 36(1)/2009) the central purpose of sub judice contempt of court is to guarantee fair hearing. As Burgess rightly surmised 'the principal aim of sub judice contempt is to prevent publications that may damage fair trial before any damage is done ${ }^{9}{ }^{89}$ Furthermore, note that a case remains sub judice until the time within which notice of appeal might be given has expired, or, if an appeal is brought, until the appeal is heard and determined. This is the common law position which still applies in Nigeria, ${ }^{90}$ Cyprus and some other common law countries (not including Britain). Hence, some of the unrestrained adverse comments in the media about the decision of the Nicosia Assize Court on the Efstathiou case before the time of appeal to the Supreme Court of Cyprus had expired and also after an appeal had been lodged and pending determination could well be contemptuous of the court and the entire Cypriot judiciary. ${ }^{91}$ In Britain, the Contempt of Court Act 1981 has given more latitude to freedom of speech by modifying the common law position in some important respects. For instance, Section 5 thereof exempts publications made as or as part of a discussion in good faith of public affairs or other matters of general public interest from the strict liability rule established under section 1 thereof 'if the risk of impediment or prejudice to particular legal proceedings is merely incidental to the discussion'. This development is well explained by Walker as follows:

Under section 2(3) of the Contempt of Court Act 1981 (UK) a publisher is not liable under the strict liability rule unless proceedings were 'active' at the time of the publication of the material. The First Schedule to the Act sets out when proceedings are 'active'. In the case of criminal proceedings, the starting point is similar to the starting point for when criminal proceedings are 'pending' rather than 'imminent'. The legislation does, however, give greater freedom to publishers than the common law as it is applied in Australia [and some other common law countries such as Cyprus]. For example, under the Act, criminal proceedings are active until there is an acquittal, sentence, verdict or discontinuance of the proceedings; appellate proceedings are active from the time they are commenced until they are disposed of or abandoned, discontinued or withdrawn. Unlike the common law position, the media are free to publish material without fear of contempt proceedings during the gap between the conclusion of proceedings at first instance and the initiation of an appeal. Furthermore, where a court remits criminal proceedings to the court below or orders a new trial, the further proceedings are active only from the conclusion of the appellate proceedings. It follows that a statement published before a retrial is ordered cannot constitute contempt on the ground only of its possible effect on a judge or jurors in any new trial. ${ }^{92}$

89 Burgess: op. cit.

90 See Fawehinmi v. A-G, Lagos State (No. 2) Nigerian Weckly Law Reports, 3 (1989) 740, Rex v. Duffy \& ors. Ex-parte Nash, All England Law Reports, 2 (1960) 891.

91 See Constantinides v. Vima Ltd. This was an application in the Supreme Court of Cyprus for stay of appeal based on the contemptuous publications in newspapers made by the appellant before the appeal was heard. The court found that the impugned publications, 'however benevolently one may interpret them...contain a scurrilous attack on the Judges who tried the case and...the judiciary as well.' [At p. 357.] Accordingly, it ordered that the appeal be stayed until the appellant restores by appropriate action the authority of the court to do justice in the case.

92 Walker, S.: Freedom of Speech and Contempt of Court: The English and Australian Approaches Compared, International and Comparative Law Quarterly, 40 (1991) 583, at 590. See also 
It is equally important to note that in most common law jurisdictions it is settled law that mere criticism of the conduct of a judge or court, even if such criticism is stronglyworded, is not contempt, as long as the criticism is fair, temperate and made in good faith. ${ }^{93}$ As the Nigerian Supreme Court has explained, 'the rationale for contempt is the need to vindicate the dignity of the court and thereby protect due administration of justice, rather than to bolster the power and dignity of the judge as an individual ${ }^{94}$ Lord Denning made the same point earlier in R. v. Metropolitan Police Commissioner, Ex parte Blackburn (No. 2). ${ }^{95}$ Yet, as argued above, such criticism may impinge on the independence of the judiciary. In Constantinides v. Vima Ltd ${ }^{96}$ the Supreme Court of Cyprus made this point as follows:

On any view of the articles complained of, however benevolently one may interpret them, they contain a scurrilous attack on the Judges who tried the case and, the Judiciary as well. Mr. Constantinides, under the guise of criticism, in the first article published three days after the delivery of judgment, questioned the impartiality of the trial Court, as well as the Judiciary... Nothing said in this judgment is designed to limit the right of the public to criticize judicial action. Not only the public-especially the press-has a right, but a duty as well to criticize judicial action whenever they think that criticism is merited in the public interest. Nobody is above the law. Least of all Judges. We are duty bound to administer justice according to law. The administration of justice is all important to the wellbeing of society and concerns everyone. We are not here confronted...with a bona fide criticism of a judgment of the Court, but with a litigant attempting to vindicate his proclaimed rights through the press, by destroying the premises upon which justice is administered, that is, the impartiality of the Judiciary. ${ }^{97}$

Contempt of Court Act 1981, schedule 1 (paras 4, 5, 11, 15 and 16). To the like effect Parker L. J. said in Attorney-General v. News Group Newspapers Ltd. [1987] QB 1, 17: '[I]t is important to remember that the Act...provides that the strict liability rule does not apply until the proceedings concerned become active. Thus a publication will be wholly protected if it happens to be made the day before High Court proceedings, the course of justice in which it is alleged that it will seriously prejudice or impede, are set down. Thereafter it will not be completely protected...' The extant law on contempt of court in Cyprus may be modified along the current British law, since the recent amendment effected by Law 36(1)/2009 did not get to this extent. Note, however, that Walker maintains that the 1981 British Act did not go as far as the Australian High Court has gone (in developing the common law) in Hinch v. Attorney-General (Victoria) Commonwealth Law Reports, (1987) 15 (High Court of Australia). See Walker, ibid, 585. For an overview of the English contempt of court law, see BradleyEwing: op. cit. 395-404.

93 See, by example, the Nigerian case of Okoduwa v. State Nigerian Weekly Law Reports, 2 (1988) 333. See also R. v. Metropolitan Police Commissioner ex parte Blackburn (No. 2), Perere v. $R$. (1951) Appeal Cases, 482.

94 Okoduwa case, at 353-354 per Nnaemeka-Agu JSC. See also Faluyi v. Oderinde, Nigerian Weekly Law Reports, 1 (1987) 155 CA; Boyo v. Midwest (1971) 1 ALL NLR 342.

95 R. v. Metropolitan Police Commissioner, Ex parte Blackburn (No. 2) 320. See also Case of Prager and Oberschlick v. Austria, para. 34.

96 See Constantinides v. Vima Ltd.

97 Constantinides v. Vima Ltd., [at pp. 357-356 and 360 respectively, per Judge Pikis]. See also ibid. 358 . 
No doubt the public has a 'right to know' and the media/press has a constitutional/ statutory and/or traditional duty to inform the public, particularly with regard to 'issues of public interest' (including judicial matters). ${ }^{98}$ The 'right to know' is based on the fundamental right to 'freedom of expression' (also called 'freedom of speech'). The grievous assaults, inhuman and degrading treatments allegedly meted to the two hapless Cypriot students by the Cyprus Police was obviously a case of public interest and the media was generally right in reporting it, subject to what is said below. As has been seen above, most observers who commented on the decision of the Nicosia Assize Court argued that it was within their constitutional right to freedom of expression-which states that 'every person has the right to freedom of speech and expression in any form ${ }^{99}$-to criticize government institutions, including courts of law. Importantly, they also suggest that the media was entirely right in its coverage of the case from the time of the unfortunate incident.

However, the point must be made that while the right to free speech is important it must not be forgotten that an accused person is equally entitled under Cypriot law and Constitution $^{100}$ as well as under the Council of Europe human rights instruments ${ }^{101}$ and international law ${ }^{102}$ to fair hearing. ${ }^{103}$ These opposing rights-right to freedom of speech/ expression and right to fair trial/hearing-can sometimes be in conflict. This is 'most likely to arise when a media organisation publishes material which may interfere with the course of particular legal proceedings'. ${ }^{104}$ As Burgess has rightly observed, 'by exercising one's right to freedom of speech one can conceivably threaten another person's right to be presumed innocent until proved guilty according to law'. ${ }^{105}$ In Attorney-General v. $M G N$ $L t d,{ }^{106}$ Schiemann LJ put the problem in perspective when he stated:

The present application focuses, as these applications usually do, on the tension between two desiderata-(1) the desire that a person facing trial should face a tribunal which is not prejudiced against him by reason of matters which have not been proved

98 See $R$. v. West [1996] 2 Criminal Appeal Reports, 374, 385-386 per Lord Taylor CJ. The same recognition is expressed in the decisions of the European Court of Human Rights (ECHR). See, by example, the Case of Prager and Oberschlick v. Austria, para. 34; Case of Worm v. Austria (83/1996/702/894), Judgment of 29 August 1997, para 50.

99 See Constitution of Cyprus 1960, Article 19(1).

100 See Constitution of Cyprus 1960, Article 30(2). See also Article 12(4) thereof.

101 For example, the European Convention on Human Rights, Article 6 provides: 'In the determination of his civil rights and obligations or of any criminal charge against him, everyone is entitled to a fair and public hearing within a reasonable time by an independent and impartial tribunal established by law...' Cyprus became a State Member of the European Union on 1 May 2004, and has been a State Party to the European Convention on Human Rights (made under the auspices of the Council of Europe) much earlier (since 6 October 1962). In fact, the Cypriot constitutional Bill of Rights was largely taken from the Convention.

102 See, by example, International Covenant on Civil and Political Rights 1966, Article 14. Article 19 thereof provides for the right to freedom of expression.

103 Everyone also has a right to reputation.

104 See Walker: op. cit. 583.

105 Burgess, op. cit. The right to be presumed innocent until found guilty according to law is guaranteed under Article 12(4) of the Constitution of Cyprus 1960.

106 Attorney-General v. MGN Ltd. [1997] Entertaintment and Media Law Reports (1997) 284; All England Law Reports, (1997) 456. 
in evidence, and (2) the desire that newspapers should be free to publish what they please. The tension is particularly strong in cases which are of widespread public interest because of the notoriety of the persons or deeds involved. The problems posed by this tension are real and recurring. ${ }^{107}$

Hence, the critical question that arises is to what extent pre-trial reporting may be properly made without the risk of prejudicing the accused's 'right to fair trial' (also called 'right to fair hearing'). ${ }^{108}$ In Sheppard v. Maxwell, ${ }^{109}$ the US Supreme court considered this question and held that the massive, pervasive, and prejudicial publicity attending the petitioner's prosecution prevented him from receiving a fair trial; and that though freedom of discussion (freedom of speech) should be given the widest range compatible with the fair and orderly administration of justice, it must not be allowed to divert a trial from its purpose of adjudicating controversies according to legal procedures based on evidence received only in open court. Accordingly, the court ordered a new trial for the petitioner/accused because of the prejudicial impact of the media publicity on his murder trial 12 years earlier.

More recently, the same approach has been sanctioned in English cases as can be seen in the case of Attorney-General v. MGN Ltd. ${ }^{110}$ In that case, there had been a period of 'saturation coverage' over a number of years about the relationship between a well-known television personality and her boyfriend. The publications disclosed his violent behaviour and details of his previous convictions. He was later arrested and charged with serious assault. Various newspapers published stories about the alleged incident. The accused applied successfully for a stay of the criminal proceedings on the ground that the press coverage of the case made it impossible for him to have a fair and impartial/unprejudiced trial. Although the present application for committal of some newspapers for contempt of court failed on its facts, this did not affect the order of stay of criminal proceedings against the accused which was made by the trial judge. In fact, the Divisional Court which heard this case observed:

The solicitor General has drawn our attention to no less than three cases in the last six months where ... a prosecution has been stayed indefinitely because of pre-trial publicity. Clearly that seriously prejudices the course of justice. There must be many others where a trial has had to be delayed or moved to a less convenient place and where it could be submitted that the course of justice has been seriously impeded. ${ }^{111}$

In a nutshell, these and other relevant authorities appear to suggest that prejudicial publications relating to criminal suspects and accused persons should be avoided in order not to imperil the path of justice. For example, previous convictions and other criminal records should not be published and the names of suspects and accused persons should not

107 Ibid. at 287-288. Similarly, Bradley and Ewing have observed that 'there is a difficult tension between the right to a fair trial and the right to freedom of expression when newspapers publish material which might prejudice the position of an accused person... One of the functions of the law of contempt of court is to manage this tension...': Bradley-Ewing: op. cit. 396. See also Scottish Daily Record, Sunday Mail Ltd. v. Procurator Fiscal, Edinburgh, Appeal Court High Court of Justiciary, (2009) 24.

108 See generally, the decision of the US Supreme Court in Nebraska Press Association v. Stuart, 49 L.Ed. 2d. 683 (1976); 427 US 539 (1976).

109 Sheppard v. Maxwell, 384 US 333 (1966).

110 Attorney-General v. MGN Ltd.

111 Ibid. 288. 
be mentioned when commenting on criminal issues of public interest which are the subject of imminent or pending judicial proceedings. Moreover, suggestions of guilt (or innocence) should be avoided: that is the job of the courts.

Although a 'pro-free speech approach'-i.e. granting greater freedom of speech and sometimes privileging the same over the right to fair trial-can sometimes be seen in contemporary UK jurisprudence (based on interpretation of the 1981 English Contempt of Court Act and following European Court of Human Rights (ECtHR) jurisprudence) ${ }^{112}$ as well as in US cases (see below), the Sheppard case approach is still generally good law in most common-law/commonwealth countries, such as Nigeria and Kenya, and there is nothing to suggest that Cypriot law is different from the general common-law/commonwealth position, except to the extent that it reflects the current position of the ECtHR.$^{113}$

Importantly, note that though the Sheppard case (as well as similar UK cases) relates to trial by jury, its principle applies with equal force to cases tried by a judge or judges alone (i.e. trial without jury). Yet, some commentators on the recent Nicosia Assize Court decision have suggested that since the case was decided by a panel of three legally qualified judges alone without a lay jury ${ }^{114}$ there was no possibility of extraneous influence-such as newspaper publications-affecting their judgment. ${ }^{115}$ For example, this was the unequivocal view of Loucaides. ${ }^{116}$ However, it is contended that this view is wrong. Undoubtedly, a judge by his training is expected to avoid adverse media publicity affecting his judgment. Nevertheless, it must be remembered that he lives in the same society as others and does and feels very much like other members of the society; hence, he could be influenced by adverse/prejudicial publicity against an accused person standing trial before him. As Justice Cardozo of the US Supreme Court has pertinently reminded us in his seminal book The nature of the Judicial Process, 'the great tides and currents which engulf the rest of men do not turn aside in their course and pass the judges by'. ${ }^{117}$ Similarly, Justice Alabi made this point extra-judicially thus:

112 See, by example, HM Advocate v. Scottish Media Newspapers Ltd. [2000] SLT 331; Cox and Griffiths, Petitioners (1998) JC 267 (High Court of Justiciary, Scotland); Attorney-General v. Independent Television News Ltd. and Others [1995] 1 Criminal Appeal Reports, 204.

113 The current position in Australia is probably more developed than what obtains under the 1981 English Contempt of Court Act. See Walker, op. cit., 584-585. See also Hinch v. AttorneyGeneral (Victoria).

114 The Jury system (a system whereby lay persons determine questions of fact, leaving the judge/judges to determine questions of law) is not used in Cypriot judicial system.

115 See Attorney-General v. BBC [1981] AC 303 (HL), at 315, per Lord Denning MR. Lord Denning's view on this was not accepted by the House of Lords in this case.

116 Another commentator expressed the same view thus: '...the rule on prior publicity, adverse or favourable, would sit better if we had trials by jury; a judge (or, worse, a group of judges sitting together) cannot rightly claim that publicity may have affected their single or collective judgment... Such hinted admission should in fact disqualify them from being a judge in the first place'. See C. Lordes, 'Our justice system is in dire need of an overhaul' [CyprusMail (Internet Edition), 25 March 2009].

117 Justice Benjamin N Cardozo, The Nature of the Judicial Process, Yale. 1921. Lecture IV: Adherence to Precedent. The Subconscious Element in the Judicial Process; referring to the 'forces which enter into the conclusions of Judges, 168. 
In the case of a trial by a judge alone, it is only in rare cases that a publication will be held to constitute a contempt... as it is accepted that judges are capable of guarding against allowing any prejudicial matter to influence them in deciding a case; but a campaign of pressure might be so great that even a judge could not be safely assumed to be unaffected by it. ${ }^{118}$ (emphasis added)

According to the Indian Supreme Court, publications which are prejudicial to a suspect or accused may also affect judges 'subconsciously', and this can be at the stage of granting or refusing bail or at the trial. In In re PC Sen, ${ }^{119}$ the Supreme Court stated that 'no distinction is, in our judgment, warranted that comment on a pending case or abuse of a party may amount to contempt when the case is triable with the aid of a Jury and not when it is triable by a Judge or Judges' ${ }^{120}$ Importantly, this reasoning and conclusion can be seen in the decision of the Supreme Court of Cyprus in Georgiades v. Republic. ${ }^{121}$ Furthermore, the point was made even much clearer by the US Supreme Court in Pennekamp v. Florida, ${ }^{122}$ thus:

No judge fit to be one is likely to be influenced consciously except by what he sees and hears in court and by what is judicially appropriate for his deliberations. However, judges are also human, and we know better than did our forbears how powerful is the pull of the unconscious and how treacherous the rational process. While the ramparts of reason have been found to be more fragile than the Age of Enlightenment had supposed, the means for arousing passion and confusing judgment have been reinforced. And since judges, however stalwart, are human, the delicate task of administering justice ought not to be made unduly difficult by irresponsible print... If men, including judges and journalists, were angels, there would be no problems of contempt of court. Angelic judges would be undisturbed by extraneous influences, and angelic journalists would not seek to influence them. ${ }^{123}$ (emphasis added)

The same point was forcefully made in England by Lord Dilhorne in Attorney-General v. $B B C:^{: 124}$

It is sometimes asserted that no Judge will be influenced in his judgment by anything said by the media and consequently that the need to prevent the publication of matter prejudicial to the hearing of a case only exists where the decision rests with laymen. This claim to judicial superiority over human frailty is one that I find some difficulty in accepting. Every holder of a judicial office does his utmost not to let his mind be affected by what he has seen or heard or read outside the court and he will not knowingly let himself be influenced in any way by the media, nor in my view will any layman experienced in the discharge of judicial duties. Nevertheless, it should, I think, be recognized that a man may not be able to put that which he has seen, heard

118 Alabi: op. cit. 184. See also R. v Davies, All England Law Reports, 2 (1945) 167.

119 In re PC Sen (1970) All India Reporter, 1970 SC 1821. SCC 592

20 Ibid., at 1829. See also Reliance Petrochemicals v. Proprietor of Indian Express (1988) 4

121 Georgiades v. Republic, 2 Cyprus Law Reports, 1 (2003) (in Greek).

122 Pennekamp v. Florida.

123 Pennekamp v. Florida, 357-366 per Justice Frankfurter.

124 Attorney-General v. BBC. 
or read entirely out of his mind and that he may be subconsciously affected by it. It is the law, and it remains the law until it is changed by Parliament, that the publications of matter likely to prejudice the hearing of a case before a court of law will constitute contempt of court punishable by fine or imprisonment or both. ${ }^{125}$

Note that in accordance with the common-law doctrine of judicial precedents, under the Cypriot legal system foreign judgments-particularly from common-law/commonwealth jurisdictions (UK, US, India, Nigeria, etc.)-are regarded as persuasive precedents whereas judgments of superior courts (particularly the Supreme Court of Cyprus) are binding on all lower courts in the country. Hence, based on the above binding and persuasive precedents, it is arguable that the Nicosia Assize Court judges were entitled to hold, as they did hold (assuming the publications, under Cypriot law, can properly be considered as tending to interfere with the outcome of the case before them ${ }^{126}$ ) that the impugned media publications 'constituted serious interference in the course of justice and pre-empted the outcome of the trial', and that 'it constitutes a usurpation of the judicial authority and contempt of court' (see above). Moreover, they were right-based on the above authorities ${ }^{127}$-to conclude that prejudicial media publications can be held to interfere with judicial proceedings pending before a judge or judges sitting with or without jurors. ${ }^{128}$ On the contrary, it is clear that the assertion of Loucaides that 'media influence is irrelevant to the proceedings, and in the cases of professional judges (with no jury), the issue of media influence does not arise' (see above) cannot be correct. In fact, there are several cases-for example Efimeris "O Filathlos" \& Anor. v. The Police ${ }^{129}$-where Cypriot judges (sitting without jury) had punished persons who published articles adjudged capable of prejudicing the fair trial of a pending judicial proceeding, for contempt of court. The position is the same under the jurisprudence of the ECtHR, contrary to the assertion of Loucaides. Surely, the decision of the ECtHR in the Case of Worm v. Austria,${ }^{130}$ mentioning the possibility of adverse pre-trial publication affecting 'lay judges' did not imply, and was clearly not intended to imply, that 'legally learned judges' cannot be affected by adverse pre-trial publications.

The same conclusions had been reached a long time ago in Nigeria and in other common law countries-especially Britain, which was the former colonial master of both Nigeria and Cyprus. The 1926 Nigerian case of Rex v. Ojukoko, ${ }^{131}$ decided by Tew, J (citing well-established English cases on the point) is a good case in point. In that case, some

125 Ibid. 335.

126 A guide can be found in several decisions of the Supreme Court of Cyprus. Under the English Contempt of Court Act 1981 (section 2(2)), two tests must be satisfied in order for publications to be held contemptuous-namely, that the publications created a 'substantial risk' and 'serious prejudice'. Moreover, the proximity of the publications to the trial is another important consideration. See Attorney-General v. News Group Newspapers Ltd., 15-16; Attorney-General v. Independent Television News Ltd. \& Others, Criminal Appeal Reports, 1 (1995) 204, at 208.

127 Especially the binding authority of Georgiades v. Republic.

128 A UK criminal court recently frowned against unfair media coverage of a pending criminal case. See 'Ibori's London case: Judge condemns unfair media coverage' (Vanguard, 23 September 2009); available at: <http://www.vanguardngr.com/2009/09/23/iboris-london-case-judge-condemns-unfair-media-coverage/> (accessed 23 September 2009).

129 Efimeris "O Filathlos" \& Anor. v. The Police, Cyprus Law Reports, 2 (1967) 249. See also Georgiades v. Republic.

130 Case of Worm v. Austria.

131 Rex v. Ojukoko (1926) 7 NLR 60. 
newspapers had published articles alluding to a theft of various articles from Government House, Lagos, and stated that the crime had been traced to an ex-convict who had only recently been discharged from prison. Following this, the Attorney-General of Nigeria made applications to the Divisional Court in Lagos for the editors of three named newspapers involved in the publications to be committed to prison for contempt of court. The editors were found guilty of contempt of court. ${ }^{132}$ In his judgment, the judge pertinently said:

It cannot be too widely made known that the publication of such statements were calculated, in the language of Lord Hardwicke in Roach v. Garvan... "to prejudice the minds of the public against persons concerned as parties in causes before the cause is finally heard", constitutes a serious contempt of court and will not be allowed to pass unnoticed or unpunished... In Rex v. Tibbits... Lord Alverstone, CJ said: ... It would, indeed, be far-fetched to infer that the articles would in fact have any effect upon the mind of either magistrate or judge, but the essence of the offence is conduct calculated to produce, so to speak, an atmosphere of prejudice in the midst of which the proceedings must go on. Publications of that character have been punished over and over again as contempts of court, where the legal proceedings pending did not involve trial by jury, and where no one would imagine that the mind of the magistrates or judges charged with the case would or could be induced thereby to swerve from the straight course. The offence is much worse where trial by jury is about to take place...

[It] is not desirable that fair and proper comment on matters of public interest should be restrained; at the same time, the public and the press should be given clearly to understand that ... [the] court will not tolerate any interference with the right of any person who may be charged with an offence to a fair and impartial trial. (emphasis added)

More importantly, under Cypriot constitutional law the right to freedom of expression is not absolute. ${ }^{133}$ The Constitution provides that the exercise of this right 'may be subject to such formalities, conditions, restrictions or penalties as are prescribed by law and are necessary only in the interests of the security of the Republic...or for the protection of the reputation or rights of others or ... for maintaining the authority and impartiality of the judiciary ${ }^{134}$ This is consistent with Article 10(2) of the European Convention on Human Rights which provides, inter alia, that the right to freedom of expression may be restricted in order to maintain the authority and impartiality of the judiciary. ${ }^{135}$ Clearly,

132 Two of them admitted responsibility and apologized to the court before the judgment in the case and were ordered to pay the costs of the proceedings; the third who did not properly apologize was additionally fined and was to be committed to prison if he failed to pay the fine within twenty-four hours.

133 Compare the First Amendment of the American Constitution (dealing with the freedom of speech and expression): though the right is couched in absolute terms, the Supreme Court has held in a long line of cases that its proper interpretation requires that it be not allowed to be used to frustrate the enjoyment of other rights; it is limited to the principle of 'clear and present danger' when it comes in conflict with the right to fair trial. See also the Fourteenth Amendment. See further Schenck v. United States, 249 U.S. 47; Frohwerk v. United States, 249 U.S. 204; Debs v. United States, 249 U.S. 211.

134 Constitution of Cyprus 1960, Article 19(3) (emphasis added).

135 See Handyside v. United Kingdom, Judgment of 7 December 1976, Series A, No. 24; 1 EHHR 737 (1979-80). 
therefore, the exercise of the right to free speech is subject, inter alia, to the law of contempt of court: it cannot be used, for instance, to publish any writing or make any speech that is capable of prejudicing the fair trial of an accused person in a judicial proceeding, ${ }^{136}$ or to publish any speech containing scandalous matter respecting any court which has adjudicated/ decided any case. ${ }^{137}$ In Constantinides v. Vima Ltd ${ }^{138}$ the Supreme Court of Cyprus categorically stated that 'Section 44 [of the Courts of Justice Law 14/60 (as amended)] limits freedom of expression safeguarded by Article 19 [of the Constitution of Cyprus 1960] for maintaining the authority and impartiality of the Judiciary,' and this is in accordance with Article 19(3) of the Constitution. ${ }^{139}$ Based on this, it is possible that some of the pre- and during as well as post- trial comments on the Efstathiou case were contemptuous of the Nicosia Assize Court specifically (as already noted, the court itself had also described the pre-trial media publicity of the case as contemptuous) and/or the Cypriot judiciary in general.

Note that it could be contempt of court all the same even if the ten policemen had been convicted of the offences with which they were charged. As Lord Alverstone stated long ago in Rex v. Tibbits: ${ }^{140}$

Though the accused be really guilty of the offence charged against him, the course of law and justice is nevertheless perverted and obstructed if those who have to try him are induced to approach the question of his guilt or innocence with minds into which prejudice has been instilled by published assertions of the guilt or imputations against his life and character to which the laws of the land refuse admissibility as evidence.

More recently, Lord Diplock re-stated the same point thus: '.. That the risk that was created by publication when it was actually published does not ultimately affect the outcome of the proceedings is... "neither here nor there". If there was a reasonable possibility that it might have done so if in the period subsequent to the publication the proceedings had not taken the course that in fact they did...the offence was complete. The true course of justice must not at any stage be put at risk'. ${ }^{141}$ In Rex v Parke,${ }^{142}$ Wills J. explained that 'the reason why the publication of articles ... is treated as a contempt of court is because their tendency and sometimes their object is to deprive the court of the power of doing that which is the end for which it exists-namely, to administer justice duly, impartially, and with reference solely to the facts judicially brought before it'. ${ }^{143}$

Having considered prejudicial publications that tend to interfere with judicial proceedings, it is now proposed to briefly advert to scandalous publications-i.e. publications scandalizing a judge or court. ${ }^{144}$ There are reasonable grounds to suggest that some of the post-judgment media attacks on the judges who decided the Efstathiou case as well as on the Cypriot judiciary in general probably scandalized the judges and the entire Cypriot

136 Courts of Justice Law 14/60, Article 44(1)(c) (as amended).

137 Courts of Justice Law 14/60, Article 44(1)(e) (as amended).

138 Constantinides v. Vima Ltd. [1983].

139 Ibid. 354.

140 Rex v. Tibbits [1902] 1 King's Bench, 77.

141 See Attorney-General v. English.

142 Rex v. Parke.

143 Cf. Hinch v. Attorney-General (Victoria).

144 See generally, Fawehinmi, G.: Nigerian Law of the Press under the Constitution and the Criminal Law. Lagos, 1987, Chapter 1 (on the aspect of the Press and Criminal Law). 
judiciary, and were contemptuous in accordance with Article 44(1)(e) of the Courts of Justice Law 14/60 (as amended). For example, the statement of Loucaides that the judges who decided the case 'may be not sufficiently trained'-a suggestion that they were not qualified to sit as judges. (Another example is the Cypriot Attorney-General's statement that Cypriots 'can't always trust court decisions': see above.) The point is that this kind of statement is not a legitimate public criticism of a judge; rather it is a 'scurrilous personal abuse of a judge with reference to his conduct as a judge in a judicial proceeding which had terminated ${ }^{145}$-and this is what makes it a contempt of court, according to wellestablished and long-standing legal authorities. ${ }^{146}$ There are several instances in the caselaw of common-law/commonwealth countries when contemnors of this species of contempt of court have been punished by the court. The same position can also be found in the jurisprudence of the European Court of Human Rights (ECtHR). ${ }^{147}$ For present purposes, it is sufficient to refer only to the facts and outcome of two such cases from national courts and one decision of the ECtHR.

Firstly, in the Nigerian case of Obiekwe Aniweta v. The State, ${ }^{148}$ an Advocate of the Supreme Court of Nigeria swore to two affidavits accusing a trial judge of corruption, and expressing his opinion that the judge is 'not fit to hold any judicial office'. By swearing them before a commissioner for oaths in a court registry, the lawyer had published the contents thereof. The trial judge considered the affidavits to be 'scandalous publications' and summarily convicted the lawyer for contempt of court after giving him an opportunity to enter his defence. Dissatisfied, the lawyer appealed to the Court of Appeal, but his appeal was dismissed for lacking merit. ${ }^{149}$ In its judgment, the Court of Appeal stated:

145 See Rex v. Horatius (1925) 6 NLR 49 per Combe C.J. See also Article 44(1)(e) of the Courts of Justice Law 14/60 (as amended).

146 This kind of contempt is punishable brevi manu (i.e. by summary process). See Mcleod v. St. Aubyn (1899) AC 549; R. v. Gray (1900) 2 QB 36; Ambard v. A-G for Trinidad and Tobago (1936) AC 322. Cf. The UK Practice Direction of 5 June 2001 (though of limited application: applies only to inferior courts). Within the Council of Europe it is no longer possible for a judge to personally try such cases summarily if they are held to constitute contempt in the face of his court. According to a learned author, 'The Kyprianou judgment [of the European Court of Human Rights] finally puts to sleep the practice that a judge can deal with contempt in the face of the court himself...Many leading authorities concerning contempt in the face of the court should be considered as obsolete, in so far as they provide for the possibility of the judge to deal with such cases himself'. See Emilianides, A. C.: Contempt in the Face of the Court and the Right to a Fair Trial: The Implications of Kyprianou v. Cyprus, European Journal of Crime, Criminal Law and Criminal Justice, 13 (2005) 401, at 412. Accordingly, the Cypriot Law 36 (2009), which recently amended Law 14/60 to implement the Kyprianou judgment, permits a continuation of summary trial of such cases, save that if the contempt affects the person of the presiding judge he cannot personally hear it.

147 Case of Prager and Oberschlick v. Austria.

148 Obiekwe Aniweta v. The State, Appeal No. FCA/E/47/78 decided on 16 June 1978. (Reported in Fawehinmi: op. cit. 98.)

149 The trial judge committed the lawyer to prison for 200 days, but this was reduced to 120 days by the Court of Appeal after upholding the conviction of the appellant, on the ground that the sentence of 200 days was 'severe'. More recently (precisely on 25 September 2009), a senior Nigerian lawyer was sentenced to three months imprisonment for contempt of court (the charge was scurrilous personal abuse of a judge with reference to her conduct as a judge in a judicial proceeding which had terminated. Briefly, the lawyer, having suffered a default judgment from the judge, filed an application to set aside the judgment and supported it with a 28-paragraph af- 
Can anyone reading the two affidavits in the present case before us say that they were genuine criticism of the learned trial judge's judgment? Our answer is No. Those affidavits had nothing to do with any criticism. They were a brutal attack on the person of the judge as a most corrupt person unfit to hold his high office. We hold the view, and we are supported by the authorities, that in the circumstances of the case, as described by the learned trial judge, it was a matter that he could try summarily on his motion, because it was a contempt committed in the cognizance of the court... [In] the words of Holroyd, J in R. v. Davison (1821) 106 ER 958...no judge would "suffer those things to pass which will make him despicable in the eyes of others. It is his duty to support the dignity of his station and uphold the law, so that in his presence, at least it shall not be infringed." 150

Among others, the Nigerian Court of Appeal relied on the English Court of Appeal decision in Balogh v. Crown Court, ${ }^{151}$ where it was said, inter alia, that in cases of scandalous publications against a judge or court it mattered not whether it was 'a case that was being tried, or about to be tried, or just over - no matter whether the judge saw it with his own eyes or it was reported to him by the officers of the court, or by others...'

The second and more recent case was a decision of the High Court of Singapore in Attorney-General v. Tan Liang Joo and Others. ${ }^{152}$ In that case, the Attorney-General of Singapore had applied to the High Court for an order committing three respondents to prison for contempt of court in that they scandalized the Singapore judiciary, inter alia, by publicly wearing a white T-shirt, imprinted with a palm-sized picture of a kangaroo dressed in a judge's gown within and in the vicinity of the Supreme Court on 26 May 2008 when a hearing was being held before Justice Belinda Ang. The applicant argued that by stigmatizing the Singapore judiciary as a 'kangaroo court' the respondents implied, inter alia, that the court was self-appointed or a mock court in which the principles of law and justice are disregarded, perverted, or parodied. In their defence, the respondents contended, inter alia, that wearing the T-shirt was an act of 'fair criticism and self-expression in the hope that the Singapore judiciary would improve from strength to strength'. They denied that they had committed any contempt and refused to apologize to the court. In her well-considered judgment, which went on excursus into the case-law of several commonwealth countries, including Britain, Australia and New Zealand, the judge rejected the defence of fair criticism and found the respondents guilty of contempt of court. In her words:

It was clear to me that this case was about much more than merely wearing a T-shirt.

The conduct of the respondents communicated to an average member of the public the

fidavit wherein he deposed, inter alia, that the judge is 'a complete failure in her capacity as a judge'). Note that the contempt charge was brought against the lawyer by the Attorney-General of Lagos state in order to protect the integrity, honour and independence of the judiciary. See 'Judge Jails Lawyer For Three Months Over Contempt' (Guardian, 26 September 2009); <http://nspace. nigeria.com/main/news/judge-jails-lawyer-three-months-over-contempt-guardian-nigeria $>$ (accessed 27 September 2009).

150 See also Rex v. Horatius; In re Ekpu (decision of a Special Military Tribunal in Lagos on 4 February 1986, convicting a journalist on a charge of contempt of court for calling the tribunal a 'Kangaroo court' in a magazine article; reported in Fawehinmi: op. cit. 573.

151 Balogh v. Crown Court, 3 All England Law Reports, (1974) 283 CA.

152 Attorney-General v. Tan Liang Joo and Others [2009] SGHC 41 (decided 18 February 2009). 
respondents' conviction that the Singapore courts are "kangaroo courts" as defined ... above... ${ }^{153}$ The respondents' conduct amounted to contumacious contempt aimed at the integrity of the courts and was designed to degrade the administration of justice. Having considered all the circumstances, I came to the conclusion that a custodial sentence was appropriate. ${ }^{154}$

With regard to the ECtHR jurisprudence, in the Case of Prager and Oberschlick v. Austria $^{155}$ the applicants had been convicted by Austrian courts for unjustified personal attacks on some Austrian judges (especially Judge J.) published in a periodical called Forum. Among others, the publication alleged that the named Austrian judges 'treat each accused at the outset as if he had already been convicted'. In this application, the applicants claimed that their conviction for contempt of $\operatorname{court}^{156}$ was a violation of their right to freedom of expression. However, after considering the circumstances of the case, the ECtHR concluded that the applicants' right to freedom of expression under Article 10 of the European Convention on Human Rights was not breached by their conviction by the Austrian courts. In an important passage of its judgment, the court stated:

Of the accusations levelled by those allegations, some were extremely serious. It is therefore hardly surprising that their author should be expected to explain himself. By maintaining that the Viennese judges "treat each accused at the outset as if he had already been convicted", or in attributing to Judge J. an "arrogant" and "bullying" attitude in the performance of his duties, the applicant had, by implication, accused the persons concerned of having, as judges, broken the law or, at the very least, of having breached their professional obligations. He had thus not only damaged their reputation, but also undermined public confidence in the integrity of the judiciary as a whole. (para. 36).

To sum up, it can be seen that courts of law have awesome powers to punish for contempt of court in order, primarily, to maintain the dignity, integrity and authority of the courts. This position remains the same today, although within the Council of Europe the jurisprudence of the European Court of Human Rights (ECtHR) dictates that, in order to ensure fair trial, contempt proceedings-particularly ex facie-should be heard by a judge other than the one against whom (and probably against whose court) it was allegedly committed. ${ }^{157}$

On the other hand, it must be noted that the courts are slow to invoke their powers of contempt to abridge the right to freedom of expression. ${ }^{158}$ The US, British and other commonwealth courts, for instance, adopt a careful balancing of the conflicting rights of free speech and fair hearing. As Lord Reid has stated in Attorney-General v. Times

153 Ibid., para. 28.

154 Ibid., para. 45.

155 Case of Prager and Oberschlick v. Austria.

156 The ECHR agreed with the government of Austria that the conviction of the accused was intended, inter alia, to maintain the authority of the judiciary. See ibid, para. 31 of the judgment.

157 See Kyprianou v Cyprus. See also Emilianides: op. cit.

158 Courts usually exercise their powers of contempt of court sparingly. In R. v. Metropolitan Police Commissioner, Ex parte Blackburn (No. 2), at p. 320 Lord Denning observed: '... [T] his court has been called on to consider an allegation of contempt against itself. It is a jurisdiction which undoubtedly belongs to us, but which we will most sparingly exercise: more particularly as we ourselves have an interest in the matter.' See also R. v. Moran, 81 Criminal Appeal Reports, (1985) 51. 
Newspapers, ${ }^{159}$ 'public policy generally requires a balancing of interests which may conflict. Freedom of speech should not be limited to any greater extent than is necessary but it cannot be allowed where there would be real prejudice to the administration of justice'. ${ }^{160}$ This approach was followed in the US in Bridges v. California. ${ }^{161}$ In that case, a litigant who had been found guilty of contempt of court for publishing a telegram wherein he had described a judge's decision as 'outrageous', while a motion for a new trial was pending, had his conviction set aside on the ground that the publication did not present 'a clear and present danger'. Mr. Justice Hugo Black, writing for the US Supreme Court, stated:

The assumption that respect for the judiciary can be won by shielding judges from published criticism wrongly appraises the character of American public opinion... An enforced silence, however limited, solely in the name of preserving the dignity of the bench, would probably engender resentment, suspicion, and contempt much more than it would enhance respect.

It is important to emphasize that this is a reasonable approach, which can also be found in a long line of cases decided by the ECtHR. In the end, it can be surmised that courts in common law jurisdictions as well as the ECtHR strive (to a greater or lesser extent in practical terms) to achieve a proper balance between freedom of expression and the need to maintain the authority and independence of the judiciary. ${ }^{162}$ The critical question remains how the balancing exercise may be conducted. A number of cases decided by the courts of common-law/commonwealth countries ${ }^{163}$ as well as the jurisprudence of the ECtHR provide some guidelines to this complex act. For present purposes, it is sufficient to briefly explain the approach of the ECtHR. Within the Council of Europe, the question is, essentially and quite often, whether an adjudged interference with the right to freedom of expression under Article 10(1) of the European Convention on Human Rights ${ }^{164}$ can be justified under any of the exceptions stated under Article 10(2) thereof. ${ }^{165}$ In which case, there would be no

159 Attorney-General v. Times Newspapers (1974) AC 273.

160 The Indian Supreme Court follows the same approach: see AK Gopalan v. Noordeen.

161 Bridges v. California, 314 US 252 (1941). This case has been followed by a long line of cases in the U.S., including Pennekamp v. Florida.

162 On the need for balance, see ECHR decision in Case of Amihalachioaie v. Moldova (Application no. 60115/00), Judgment of 20 April 2004, para. 28.

163 See, for example, Hinch v. Attorney-General (Victoria); Attorney-General v. English; Attorney-General v. News Group Newspapers Ltd. See also Walker: op. cit. 594-595.

164 The 1950 European Convention on Human Rights greatly influenced the Bill of Rights found in the Constitution of most commonwealth countries. In fact, the Convention provisions are in most cases reproduced verbatim.

165 Article 10 provides in full as follows:

1. Everyone has the right to freedom of expression. this right shall include freedom to hold opinions and to receive and impart information and ideas without interference by public authority and regardless of frontiers. This article shall not prevent States from requiring the licensing of broadcasting, television or cinema enterprises.

2. The exercise of these freedoms, since it carries with it duties and responsibilities, may be subject to such formalities, conditions, restrictions or penalties as are prescribed by law and are necessary in a democratic society, in the interests of national security, territorial integrity or public safety, for the prevention of disorder or crime, for the protection of health or morals, for the protection of the reputation or the rights of others, for preventing the disclosure of information received in confidence, or for maintaining the authority and impartiality of the judiciary. 
violation of Article 10(1). Importantly, to reach a conclusion one way or the other involves examining the interference to determine whether it is prescribed by an existing law; whether the aim pursued by the interference was legitimate; and whether it is necessary in a democratic society, inter alia, for maintaining the authority and impartiality of the judiciary. If any of these considerations fail, then the interference would be held to violate the right to freedom of expression. In the Case of Amihalachioaie v. Moldova ${ }^{166}$ the ECtHR explained as follows:

In performing its supervisory role, the Court [ECtHR] has to look at the interference complained of in the light of the case as a whole, including the tenor of the applicant's remarks and the context in which they were made, and determine whether it "correspond[ed] to a pressing social need", was "proportionate to the legitimate aim pursued" and whether the reasons adduced by the national authorities to justify it are "relevant and sufficient" (see The Sunday Times (no. 2)..., and Nikula v. Finland, no. 31611/96, § 44, ECHR 2002-II). (para. 30). ${ }^{167}$

Note that within the Council of Europe the assessment of these factors falls in the first place to the national authorities (including an independent court), which enjoys a certain margin of appreciation in determining the existence and extent of the necessity of an interference with the freedom of expression. ${ }^{168}$

Nevertheless, while the balancing approach remains generally true in most commonlaw/commonwealth countries, a pro-freedom of the press/freedom of speech approach can be observed in several decisions of the ECtHR ${ }^{169}$ as well as decisions of US courts (e.g. Bridges case) and English courts (particularly since the 1981 English Contempt of Court Act was made and following ECtHR jurisprudence). As Lloyd L.J. observed in AttorneyGeneral v. Newspaper Publishing Plc: ${ }^{170}$

[T]he statutory purpose behind the 1981 Act was to effect a permanent shift in the balance of public interest away from the protection of the administration of justice and in favour of freedom of speech. Such a shift was forced on the United Kingdom by the decision of the European Court [of Human Rights] in The Sunday Times v. U.K... ${ }^{171}$

166 Case of Amihalachioaie v. Moldova. See also Jersild v. Denmark, Judgment of 23 September 1994 (Series A no. 298); Case of Prager and Oberschlick v. Austria, para. 35; Case of Kobenter and Standard Verlags GMBH v. Austria (Application no. 60899/00), Judgment of 2 November 2006.

167 The ECHR found in this case that even though the impugned critical remarks may be regarded as showing a certain lack of regard for the Constitutional Court of Moldova following its decision on the constitutionality of legislation regulating the legal profession, they cannot be described as grave or as insulting to the judges of the court. Accordingly, it was held that restricting the applicant's right to freedom of expression (he was ordered to pay administrative fine for his remarks) was a violation of his right to freedom of expression under Article 10 of the European Convention on Human Rights.

168 See Case of Prager and Oberschlick v. Austria, para. 35.

169 See, by example, The Sunday Times v. United Kingdom (Series A No 30), European Court of Human Rights (1979-1980) 2 European Human Rights Reports, 245, Judgment of 26 April 1979; The Times (No. 2) v. The United Kingdom (Application no. 13166/87), Judgment of 26 November 1990; Case of Amihalachioaie v. Moldova.

170 Attorney-General v Newspaper Publishing Plc, 3 All England Law Reports, (1987) 276.

171 Ibid, 310; Attorney-General v. Newspaper Publishing Plc [1988] Ch. 333, at 382. 
A similar statement, albeit not quite extremist as the above, can also be found in the judgment of the Supreme Court of Cyprus in Cosmos Press Ltd \& Anor. v. The Police: ${ }^{172}$

In the light of the modern trend in interpreting and applying provisions relating to human rights, such as Article 19 of our Constitution and corresponding Article 10 of the European Convention on Human Rights, which forms part of our own law as well, [see European Convention on Human Rights (Ratification) Law 1962-Law 39/62] and in the light, also, of weighty dicta such as those of the European Court of Human Rights in the judgment of "The Sunday Times case,"... section 122(b) of Cap. 154, which is a restriction of the right of expression, must be applied in each particular case in a manner as favourable as possible for the freedom of the press.

Even so, this does not spell the end of criminal contempt of court; it only means that the courts are slow to abridge the right to freedom of speech but in clear cases it will still find certain publications, for instance, as contemptuous. ${ }^{173}$ This is arguably the current position in Cyprus, given that it is a reflection of the jurisprudence of the ECtHR. ${ }^{174}$

\section{Concluding Remarks}

The recent Efstathiou case decision in Cyprus has provided an opportunity to re-appraise the issues of independence of the judiciary, trial by media and fair trial in the country as well as the closely linked issue of contempt of court. While there is no suggestion that the Cypriot judiciary has no independence, the case has raised issues which threaten the independence - for example, whether the right to freedom of speech can be used to interfere with judicial proceedings or engage in scurrilous abuse of a judge because of his judicial opinion in a case.

As could be observed from various cases cited here from various common-law jurisdictions, in criminal contempt of court cases-particularly with regard to prejudicial and scandalous publications-the application to commit the accused to prison for contempt of court is normally brought by the Attorney-General of the State. ${ }^{175}$ This is also true in the Republic of Cyprus, as suggested by the Supreme Court in Constantinides v. Vima Ltd. ${ }^{176}$ Note that this position is based on constitutional and/or statutory provisions that invest the Attorney-General with the power to commence and/or discontinue all criminal prosecutions (including the criminal offence of contempt of court). More importantly, this is a preeminent way by which the Attorney-General ensures the maintenance of respect, honour and dignity for the judiciary or, to put it differently, the protection and defence of the independence of the judiciary. ${ }^{177}$ In the Republic of Cyprus, the prosecutory power of the

172 Cosmos Press Ltd. \& Anor v. The Police, Cyprus Law Reports, (1985) 73, at 81.

173 See, by example, Attorney-General v. Express Newspapers England and Wales High Court, (2004) 2859 (Admin); Attorney-General v. MGN Ltd.; Scottish Daily Record, Sunday Mail Ltd. v. Procurator Fiscal, Edinburgh. See generally Attorney-General of the Republic v. Efstathiou.

174 See, by example, Case of Worm v. Austria; Case of Prager and Oberschlick v. Austria. See generally Attorney-General of the Republic v. Efstathiou.

175 In Australia it is possible for any person to bring an action alleging contempt of court by publication. See R. v. Dunbabin, 53 Commonwealth Law Reports, (1935) 434 (High Court of Australia), at 445 (per Rich J.). See also Walker: op. cit. 588.

176 Constantinides v. Vima Ltd., at 353.

177 It is also the case that the Attorney-General of a State normally responds to public criticisms of judges. See, by example, C. Dyer, 'Plea for end to attacks on Woolf' (Guardian, 13 Novem- 
Attorney-General is provided in Article 113(2) of the Constitution of Cyprus 1960 which states that:

The Attorney-General of the Republic shall have power, exercisable at his discretion in the public interest, to institute, conduct, take over and continue or discontinue any proceedings for an offence against any person in the Republic. Such power may be exercised by him in person or by officers subordinate to him acting under and in accordance with his instructions. ${ }^{178}$

The recent sad development in Cyprus, where the Attorney-General was himself probably liable for contempt of court, has revealed the limitation of this position and raised the question 'who prosecutes the prosecutor?'179 This is particularly serious having regard to the decision of the European Court of Human Rights (ECtHR) in Kyprianou case. ${ }^{180}$ In that case, a Cypriot trial court had convicted a lawyer for alleged contempt in the face of the court (the lawyer suggested that a male and female member of a 3-member panel of judges were sending 'love notes' to each other while he was conducting his case for his client before them instead of listening to him) and sentenced him to a term of imprisonment. ${ }^{181}$ However, the conviction and sentence were set aside on the application of the lawyer to the ECtHR on the ground that it breached his right to a fair trial guaranteed under Article 6 of the European Convention on Human Rights. According to the court (ECtHR), the proper thing to do is to 'refer the question to the competent prosecuting authorities for investigation and, if warranted, prosecution, and to have the matter determined by a different bench from the one before which the problem arose'. ${ }^{182}$

Importantly, the Cypriot government has recently amended the Cypriot contempt of court law in order to bring it in line with the Kyprianou case decision of the ECtHR. ${ }^{183}$ Essentially, Article 44(3) of the Courts of Justice (Amendment) Law 36(1)/2009 forbids a Cypriot judge from trying an ex facie contempt of court case where the act constituting the contempt affects the judge personally. ${ }^{184}$ Moreover, under Article 44(9) of Law 36(1)/2009 lawyers conducting cases before a court are immune from the offence of contempt of court in the face of the court. ${ }^{185}$ The reason for this is said to be 'the need to safeguard freedom of

ber 2004); <http://www.guardian.co.uk/uk/2004/nov/13/ukcrime.media> (accessed 12 May 2009). The Plea was made by Lord Goldsmith, Attorney-General of the UK, in defence of Lord Chief Justice Lord Woolf who was suffering persistent press attack.

178 See. Loizu, A. N.-Pikis, G. M.: Criminal Procedure in Cyprus. Nicosia, 1975.

179 The difficulties of this situation can be gleaned from the recent Ruling of the Supreme Court of Cyprus in Attorney-General of the Republic v. Efstathiou (Supreme Court Ruling of 8 October 2009).

180 See Kyprianou v. Cyprus. For a useful comment on this decision, see Emilianides: op. cit.

181 The lawyer's appeal to the Supreme Court of Cyprus was unsuccessful.

182 Kyprianou v. Cyprus, para. 37.

183 See Courts of Justice (Amendment) Law 36(1)/2009.

184 Query: Did the amendment effected by the Courts of Justice (Amendment) Law 36(1)/2009) fully comply with the ECHR decision in the Kyprianou case? A Cypriot Advocate and scholar, Dr Achilles Emilianides, answers this query in the affirmative (email communication, 21/09/09).

185 On grounds of public policy, they are also immune from an action for negligence at the suit of a client in respect of their conduct or management of a cause in court. See Rondel v. Worsley, 1 Appeal Cases, (1969) 191, at 227. This is no longer the case in England. See Arthur J.S. Hall and Co. v. Simons, 1 Appeal Cases, (2002) 615. 
expression and speech of advocates and the right to a fair trial of parties represented by the advocates'. ${ }^{186}$ (Further amendment in line with the English Contempt of Court Act 1981 may be considered in order to further enlarge the right to freedom of expression). However, acts which hitherto would have constituted contempt of court ex facie within the meaning of Article 44(1) of Law 14/60 (as amended by Law 36(1)/2009) - for example showing disrespect to a court by word or conduct - are now regarded as a 'disciplinary offence'187 triable by the Disciplinary Board ${ }^{188}$ established by the Advocates Law, ${ }^{189}$ and headed by the Attorney-General. ${ }^{190}$ This position may have been brought about by the suggestion of the ECtHR in the Kyprianou case that punishing lawyers for contempt committed during their conduct of a client's case in court could have a 'chilling effect' on the performance of lawyers in court. However, it is contended that the court was not advocating immunity for lawyers from ex facie contempt of court; rather, it was urging judicial restraint when considering a contempt case affecting a lawyer and in sentencing a contemnor lawyer in order to strike a fair balance between the need to protect the authority of the judiciary on the one hand and on the other hand the protection of the lawyer's freedom of expression in his professional capacity.

From the foregoing, one can deduce two implications. First, the Nicosia Assize Court (and, indeed, other courts in Cyprus) is effectively powerless against anyone who commits contempt in the face of the court (ex facie contempt of court)-specifically, where the act constituting the contempt 'turns against the person of the judge of the said court'. ${ }^{191}$ Although an affected court/judge has power under Article 44(3) of the Courts of Justice (Amendment) Law 36 (1) 2009 to 'refer the case and the relative proceedings to the President of the Supreme Court, in order for the latter to appoint another court to adjudicate the offence', in the case of an Attorney-General it seems that such a reference is potentially ineffective as he could invoke his constitutional power to discontinue the case. Secondly, a deliberate act of disrespect by a lawyer (including the Attorney-General) who is conducting a case before a court does not constitute the offence of contempt of court but merely a disciplinary offence, which may be tried by a Board headed by the Attorney-General. All of this probably explains why Attorney-General Petros Clerides interfered with impunity with the reading of the judgment in the recent Efstathiou case. ${ }^{192}$

186 Courts of Justice (Amendment) Law 36(1)/2009, Article 44(9).

187 Ibid.

188 Ibid.

189 Advocates Law, Cap 2 (as amended). The court before which the disrespect occurred may refer the matter to the Disciplinary Board, which is required to examine the conduct 'as a matter of urgency'. See Courts of Justice (Amendment) Law 36(1)/2009, Article 44(9).

190 There are six other members of the Board, apart from the Attorney-General. See Cyprus Bar Association, 'The Board Members' < http://www.cyprusbarassociation.org/ thebodymembers_en.php> (accessed 21 October 2009).

191 See Courts of Justice (Amendment) Law 36(1)/2009), Article 44(3). See also generally Article 44 (2)-(10).

192 It must be mentioned that though the Courts of Justice (Amendment) Law 36 (1) 2009) was passed shortly after the Efstathiou case was decided, it was never in doubt in Cyprus that the ECHR decision in the Kyprianou case effectively precluded the Nicosia Assize Court from taking any action against the Attorney-General when he interfered with the reading of the judgment in the case. Furthermore, the conduct of the Attorney-General and other justice officials following the acquittal of the ten policemen charged with offences in the Efstathiou case has been condemned in an article in the CyprusMail. After recounting their various reactions and public statements, it was concluded: 
Regrettably, while Law 36(1)/2009 may have been well-intentioned, it seems it has unwittingly added to the power of the Cypriot Attorney-General in a manner that may well be contrary to the rule of law and democracy. Prior to the amendment, a Cypriot AttorneyGeneral was an established powerful State officer ${ }^{193}$-the Attorney-General's office is an independent office ${ }^{194}$ and the occupant enjoys security of tenure ${ }^{195}$ and salary ${ }^{196}$ (he cannot easily be removed from office nor can his salary be reduced) unlike the case in some commonwealth countries (such as Nigeria) where the Attorney-General's office is at the pleasure of the Head of Government. In the interests of justice, the rule of law and democracy, it is strongly recommended that the Cypriot government should consider amending the prosecutory and other laws appropriately to ensure that the prosecutor is not above the law nor have the semblance of being above the law in any way, although it must be acknowledged that this may not be easily achieved within the complex Cypriot constitutional context.

The Cypriot judiciary has truly helped the country, even as recognized by the President of the Cyprus Bar Association Doros Ioannides. The celebrated Supreme Court of Cyprus decision in Attorney-General of Cyprus v. Mustapha Ibrahim, ${ }^{197}$ eloquently illustrates this point. That was the case where both Greek and Turkish Cypriot judges cooperated to render a decision which has helped to hold the fabric of the Cypriot society together on the doctrine of 'state necessity' since the 1964 inter-communal clashes led to the enduring problem of the country. ${ }^{198}$ More recently, the contribution of the Cypriot judiciary to the general interests of the citizenry can be seen in the landmark decision in the Orams case, which the European of Justice (ECJ) recently ruled to be binding and legally enforceable throughout

We have an Attorney-general [AG] who does not completely trust the justice system, a deputy AG who feels that judges get things wrong and a senior counsel who insists that many police officers are corrupt crooks. And these officials are supposed to work together with the allegedly corrupt police in order to prosecute suspected law-breakers? They are also supposed to cultivate respect for the law, the justice system and the state, but they are doing the exact opposite. How can they serve the very state in which they have so little faith and have gone out of their way to discredit? Only they could answer. See 'What sort of example are our justice officials setting?'.

193 It is perhaps a measure of the degree of contempt with which the Attorney-General holds the Cypriot judiciary that he chose to reward a possible contemnor, Loukis Loucaides, with a fat brief-counsel for the State-Appellant in the Efstathiou case-instead of prosecuting him for contempt of court as would have happened elsewhere. A commentator also thinks that the choice of Loucaides (former ECHR judge now in private legal practice) was wrong for other reasons. See Charalambous, L.: Of all the lawyers to appeal the beatings ruling, why Loucaides? [CyprusMail (Internet Edition), 10 May 2009].

194 Constitution of Cyprus 1960, Article 112(2).

195 Constitution of Cyprus 1960, Article 112(4).

196 Constitution of Cyprus 1960, Article 166(1)(b). See further Article 153 (7)-(12).

197 Attorney-General of Cyprus v. Mustapha Ibrahim, Cyprus Law Reports, (1964) 195.

198 Following inter-communal clashes (Greek versus Turkish Cypriots) in 1963 and the attempted military coup in 1974, Turkey had invaded and occupied the northern part of Cyprus since 1974; thus effectively partitioning the small Island country (it is estimated that Turkey is occupying some 37\% of the country: an area which the Turkish Cypriots now call Turkish Republic of Northern Cyprus, recognized only by the Republic of Turkey). Presently, there are discussions and negotiations between the President of Cyprus and the political leader of the occupied part of Cyprus (Turkish Cypriot leader) towards finding a solution to the problem and ending the Turkish occupation (dubbed re-unification talks). 
the European Union. ${ }^{199}$ In that case, a Cypriot court had decided in favour of a Greek Cypriot who claimed title to land located in the Turkish occupied northern Cyprus on which a British couple had built a villa.

The point must be made that without independence, no judiciary can satisfactorily play its important role in the society, not least the Cypriot judiciary. Yet, it was the case that the reactions and comments which followed the Efstathiou case decision greatly impinged on the independence of the judiciary as explained above. Among others, the reactions and comments grossly violated the prescriptions of Article 2 of the Universal Charter of the Judge 1999, which states that 'the Judge, as a holder of judicial office, must be able to exercise judicial powers free from social, economic and political pressure', and Principle 1(d) of Recommendation No. R (94) 12 of 1994 (on the independence, efficiency and role of Judges) of the Council of Europe, which states, inter alia, that 'judges should be independent and be able to act without any restriction, improper influence, inducements, pressures, threats or interferences, direct or indirect, from any quarter or for any reason'. In the end, given the importance of the judiciary in any democratic society as shown above and having regard to the fact that it cannot properly function without independence and public confidence in it, nothing should be done that may destroy the independence of the Cypriot judiciary in any way.

Furthermore, lawyers must remember that their special status in the society gives them a central position in the administration of justice 'as intermediaries between the public and the courts', and that this position leads to restrictions on their conduct. So, while they, like other members of the society, can comment in public on the administration of justice, their criticism must not overstep certain bounds: it must not degrade the courts. ${ }^{200}$ In the Case of Schöpfer v. Switzerland, ${ }^{201}$ the ECtHR reiterated that 'the courts-the guarantors of justice, whose role is fundamental in a State based on the rule of law-must enjoy public confidence... ${ }^{202}$ Regard being had to the key role of lawyers in this field, it is legitimate to expect them to contribute to the proper administration of justice, and thus to maintain public confidence therein'. Undoubtedly, the comments of most Cypriot lawyers (including the Attorney-General of Cyprus) regarding the decision in Efstathiou case undermined the public confidence in the judiciary instead of contributing thereto. ${ }^{203}$ In fact, as already suggested above, the statements of Loucaides and Attorney-General Petros Clerides

199 See B. Waterfield, 'Landmark court ruling means Britons could be forced to return homes in Northern Cyprus' (Telegraph, 29 April 2009); available at: <http://www.telegraph. co.uk/news/worldnews/europe/cyprus/5242294/Landmark-court-ruling-means-Britons-couldbe-forced-to-return-homes-in-Northern-Cyprus.html $>$ (accessed 9 May 2009). See also S. Bahceli, 'Orams lose at Court of Justice' [CyprusMail (Internet Edition), 29 April 2009], Although some, particularly Turkish Cypriots, contend that the Orams decision will complicate the ongoing reunification talks, Greek Cypriots are generally exhilarated by the decision. As at 20 October 2009, there is no evidence that that decision has caused any significant obstacle to the progress of the talks.

200 See Case of Amihalachioaie v. Moldova, paras. 27 and 28.

201 Case of Schöpfer v. Switzerland, Judgment of 20 May 1998, Reports 1998-III, para. 29. See also Casado v. Spain, Judgment of 24 February 1994, Series A no. 285-A. See also Veraart v. The Netherlands (Application No. 10807/04), Judgment of 30 November 2006, para. 51; Case of Steur v. The Netherlands (Application no. 39657/98), Judgment of 23 October 2003, para. 38.

202 See also Case of Prager and Oberschlick v. Austria, para. 34.

203 See generally Citizens for Independent Courts, Uncertain Justice: Politics and America's Courts (New York 2000), esp. at 149. 
amounted to scurrilous attack on the trial judges and the Cypriot judiciary 'under the guise of criticism'. ${ }^{204}$

The media is equally important to the Cypriot society, as elsewhere in the world. In fact, neither the judiciary nor the media is more important than the other in a democratic society. Hence, what is needed is a thorough recognition of the limits of all institutions of government. Moreover, it must be noted that while freedom of speech is important in a democratic society, it is not an absolute right. It cannot be used, for instance, to peddle dirt in terms of defamatory statements or in terms of scurrilous abuse of the judicial system or to interfere with judicial proceedings. In the end, a fitting conclusion to this article is the following immortal words of Justice Frankfurter in the US Supreme Court in 1946:

Without a free press there can be no free society. Freedom of the press, however, is not an end, in itself, but a means to the end of a free society. The scope and nature of the constitutional protection of freedom of speech must be viewed in that light, and in that light applied. The independence of the judiciary is no less a means to the end of a free society, and the proper functioning of an independent judiciary puts the freedom of the press in its proper perspective. For the judiciary cannot function properly if what the press does is reasonably calculated to disturb the judicial judgment in its duty and capacity to act solely on the basis of what is before the court. A judiciary is not independent unless courts of justice are enabled to administer law by absence of pressure from without, whether exerted through the blandishments of reward or the menace of disfavour. ${ }^{205}$

204 This was an expression of the Supreme Court of Cyprus in Constantinides v. Vima Ltd., at p. 357. See generally Attorney-General of the Republic v. Efstathiou (Supreme Court Ruling of 8 October 2009).

205 Pennekamp v. Florida, at 354-357. The Judge said more: In the noble words, penned by John Adams, of the First Constitution of Massachusetts: "It is essential to the preservation of the rights of every individual, his life, liberty, property, and character, that there be an impartial interpretation of the laws, and administration of justice. It is the right of every citizen to be tried by judges as free, impartial, and independent as the lot of humanity will admit." A free press is not to be preferred to an independent judiciary, nor an independent judiciary to a free press. Neither has primacy over the other; both are indispensable to a free society. The freedom of the press, in itself, presupposes an independent judiciary through which that freedom may, if necessary, be vindicated. And one of the potent means for assuring judges their independence is a free press. A free press is vital to a democratic society because its freedom gives it power. Power in a democracy implies responsibility in its exercise. No institution in a democracy, either governmental or private, can have absolute power. Nor can the limits of power which enforce responsibility be finally determined by the limited power itself... In plain English, freedom carries with it responsibility even for the press; freedom of the press is not a freedom from responsibility for its exercise...These are generalities. But they are generalities of the most practical importance in achieving a proper adjustment between a free press and an independent judiciary. Especially in the administration of the criminal law-that most awesome aspect of government-society needs independent courts of justice. This means judges free from control by the executive, free from all ties with political interests, free from all fears of reprisal or hopes of reward. The safety of society and the security of the innocent alike depend upon wise and impartial criminal justice. Misuse of its machinery may undermine the safety of the State; its misuse may deprive the individual of all that makes a free man's life dear. Ibid. 